\title{
Hydrogeochemical analysis and identification of solute sources in the meltwater of Chaturangi glacier, Garhwal Himalaya, India
}

\author{
Harish Bisht ${ }^{1}(1) \cdot$ Bahadur Singh Kotlia ${ }^{1} \cdot$ Kireet Kumar $^{2} \cdot$ Ajay Kumar Taloor $^{3} \cdot$ Prakash Chandra Arya $^{4}$. \\ Saurabh Kumar Sah ${ }^{2} \cdot$ Vasudha Agnihotri $^{2} \cdot$ Mohit Tewari $^{2} \cdot$ Rajeev Upadhyay ${ }^{1}$
}

Received: 8 July 2021 / Accepted: 30 September 2021 / Published online: 7 February 2022

(c) The Author(s) 2022

\begin{abstract}
This paper presents an insight on major ion chemistry and identification of solute sources in meltwater of Chaturangi glacier throughout the ablation period 2015 and 2016. The results indicate that meltwater is slightly acidic with $\mathrm{Ca}-\mathrm{HCO}$ and $\mathrm{Mg}-$ $\mathrm{HCO}_{3}$ dominated hydrochemical facies. In meltwater, $\mathrm{Ca}^{2+}$ and $\mathrm{HCO}_{3}{ }^{-}$are the most dominant cation and anion, respectively. The Water Quality Index values show that the quality of meltwater is good for both the ablation seasons. An important factor governing the quality of water is the residence time for dissolving minerals from the rocks. Mineralogy of surrounding rocks and Gibbs plot suggest that the meltwater ionic concentration is mostly controlled by weathering of rocks with slight contribution from atmospheric aerosols. For meltwater, the average equivalent ratios of $\mathrm{Na} / \mathrm{Cl}$ and $\mathrm{K} / \mathrm{Cl}$ were calculated as $3.36 \pm 1.29$ and $2.29 \pm 0.62$ in 2015 and $1.39 \pm 0.6$ and $0.8 \pm 0.2$ in 2016 , which are considerably higher than the marine aerosols $(\mathrm{Na} / \mathrm{Cl}=0.85$ and $\mathrm{K} / \mathrm{Cl}=0.017)$, it also confirmed the less contribution of atmospheric input in meltwater. The petrographic analysis of surrounding rocks indicate positive relationship among the cations $\left(\mathrm{Ca}^{2+}, \mathrm{Mg}^{2+}, \mathrm{Na}^{+}\right.$and $\left.\mathrm{K}^{+}\right)$and mineral abundance. Our observations suggest that the bedrock mineralogy and weathering reactions together with amount and composition of atmospheric inputs are the main sources of ions, dissolved in the glacier meltwater. It might be due to rate of chemical reaction which leads decomposition of rocks and leaching of minerals into the meltwater. Additionally, the geology of the area plays a significant as the influence of geology and climate on water quality is observed by the quantity and types of dissolved materials and amount of the sediment carried by the streams. The elevated proportion of $\mathrm{Ca}+\mathrm{Mg}$ in total cations and high $\mathrm{Ca}+\mathrm{Mg} /(\mathrm{Na}+\mathrm{K}$ ratios, $1.47 \pm 0.14$ in the year 2015 and $1.44 \pm 0.28$ in 2016 clearly reveal that the ionic composition is primarily controlled by carbonate weathering and partly by silicate weathering. Further, the low $\mathrm{Na}+\mathrm{K} /$ $\mathrm{TZ}^{-}$ratio $(0.41 \pm 0.02)$ and $(0.22 \pm 0.05)$ in 2015 and 2016 , respectively also supports that carbonate weathering is main geochemical process controlling the hydrochemistry of meltwater. In addition, the ion denudation rate was calculated for both the years. The results show that the cation denudation rate of meltwater was 32.84 and 22.30 ton $/ \mathrm{km}^{2} / \mathrm{ablation}$ during 2015 and 2016, respectively, whereas the anion denudation rate was found to be 205.43 in 2015 and 170.24 ton $/ \mathrm{km}^{2} / \mathrm{ablation}$ in 2016 .
\end{abstract}

Keywords Chaturangi glacier $\cdot$ Chemical weathering $\cdot$ Denudation rate $\cdot$ Hydrogeochemistry $\cdot$ Mineralogy $\cdot$ Water quality index

\section{Introduction}

In general, the Himalaya holds the largest amount of snow and ice outside from the polar areas (Kulkarni and Karyakarte 2014) with a total of 9,575 glaciers, covering an area of approximately 40,000 km² (Raina and Srivastava 2008), thus is called as the "Water Tower of Asia" (Dyurgerov and

Harish Bisht

harishbisht890@gmail.com

Extended author information available on the last page of the article
Maier 1997; Sood et al. 2021a, b). The Himalayan glaciers are situated at an altitude above $3,500 \mathrm{~m}$, away from the settlement of human inhabitants (Thayyen et al. 2007). The glaciers of central and eastern Himalaya receive moisture from the Indian Summer Monsoon (ISM), while the glaciers of western Himalaya pick up a major part of the moisture from the Indian Winter Monsoon (IWM) (Dimri et al. 2016; Sharma et al. 2016; Sood et al. 2020). Hydrogeochemical study of the meltwater drained from different glaciers is important because of increasing requirement of freshwater in downstream regions (Bisht et al. 2018). The hydrochemistry 
(e.g., $\mathrm{pH}$, conductivity, dissolved ions) of glacier meltwater can be used to identify different sources as well as information on the internal hydrology of the glaciers (Azetsu-Scott et al. 2012; Kristiansen et al. 2013). The pollutants in the natural water resources can be classified into contaminants of physical, biological and chemical origin according to their properties (Qian et al. 2004). The avoidance of water pollution is essential than the remediation of polluted water. In the recent years, water resources of the meltwater have been gradually polluted particularly due to anthropogenic activities and geogenic agents, as a result, regular monitoring of these assets seems vital to ensure their remaining fraction potable (Narany et al. 2014; Bisht et al. 2018). Onsite collection and measurements of water samples are mainly used to assess water quality and these are precise for a point in space and time but do not give either the temporal or spatial view of water quality in a wider space. Therefore, the Geographical Information System (GIS) and Remote Sensing (RS) technologies are useful tools in monitoring and evaluating few parameters for water quality (Usali and Ismail 2010). The advanced technology in the fields of GIS and RS has made it feasible to perform water quality monitoring and remediation studies. By using recent advanced spatial and spectral resolution sensors and geospatial modeling techniques, water quality parameters such as turbidity, suspended sediments, algae bloom, chlorophyll-a and mineral content in water resources are being monitored with high precision at low cost (Gholizadeh et al. 2016; Ramadas and Samantaray 2018). While, the RS technique is suitable for monitoring and management of water quality, the GIS method is valuable in data collection and hazards related water quality. In a nutshell, a combination of GIS technologies with field based studies is widely used to examine the water contamination zones as well as sources of contamination.

The hydrogeochemical study provides information about local geology, weathering type, load of material into ocean and atmospheric precipitation (Xu et al. 2010). Hydrogeochemical characterization of glacier meltwater varies from glacier to glacier, largely due to different lithology (Collins 1979). The geology of the catchment is one of the main factors, responsible for affecting the glacier meltwater chemistry and thereby, the quality of meltwater. The water, draining from the glaciers comes in contact with the different lithounits and soil particles, and subsequently gets influenced by different mineral constituents. In meltwater streams, a variety of solutes are generally obtained from weathering of surrounding rocks including small contribution from atmospheric aerosols (Kumar et al. 2009) which in turn is mainly influenced by lithology, soil cover, rainfall, discharge, temperature and relief (Raymo and Ruddiman 1992; Noh et al. 2009; Shin et al. 2011). The chemical weathering processes are more powerful in glacial area than the tropical region (Souchez and Lemmens 1987), the higher rate in former is primarily because of higher contact time of meltwater to surrounding bedrock (Singh et al. 2012). Clow and Mast (2010) suggested that the rock forming minerals supply ions through chemical weathering, which generally manage the stream hydrochemistry. Glaciated regions are ideal environment to study rock-water interaction and its role in solute dynamics of glacier meltwater (Sah et al. 2017). In glacial environment, the chemical weathering of surrounding rocks is primary source of ion concentration in the meltwater even though the secondary source is atmospheric precipitation (Hallet 1976). The dissolved ionic and elemental fluxes, transported by streams are regulated through the process of chemical weathering of rocks, while the transport of particulate is assumed by mechanical weathering (Krishnaswami and Singh 2005).

For Himalayan glaciers, the hydrochemical studies are less documented as compared to the Alpine and Arctic glaciers, probably due to complexity in the data collection from higher elevations (Singh et al. 2014a). However, some studies (Kumar et al. 2009; Singh et al. 2012, 2013, 2014a, b; Sah et al. 2017; Bisht et al. 2021) have been dealt with the hydrochemistry of Gangotri glacier meltwater and its tributaries. However, no study has been carried out on the detailed hydrogeochemistry of tributary glaciers because of limited dataset and shortage of seasonal meltwater sampling. Therefore, to fulfill this gap, we have attempted an integrated approach to investigate the major ion chemistry, ionic flux, water quality analysis, detailed hydrogeochemical weathering processes and identification of ionic sources of meltwater, draining from Chaturangi glacier by obtaining the data set of ablation periods of 2015 and 2016.

\section{Study area and regional geology}

The Chaturangi glacier $\left(30^{\circ} 54^{\prime} 08^{\prime \prime}-30^{\circ} 54^{\prime} 28^{\prime \prime} \mathrm{N}: 79^{\circ} 15^{\prime}\right.$ $\left.19^{\prime \prime}-79^{\circ} 6^{\prime} 18^{\prime \prime} \mathrm{E}\right)$, situated in Uttarkashi district of Uttarakhand, India (Fig. 1), is east-west-flowing $21.1 \mathrm{~km}$ long valley glacier and has approximately $43.83 \mathrm{~km}^{2}$ glaciated area (Bisht et al. 2019) and around $214.8 \mathrm{~km}^{2}$ catchment area (Orr et al. 2019). It is the longest inactive (not joined with main trunk) tributary of the Gangotri glacier, earlier was connected to Gangotri until 1971 (Vohra 1988; Bisht et al. 2020b), and detached from the main trunk after 1989 (Bisht et al. 2019). At present, the Chaturangi glacier snout (Fig. 2a) is situated at $4,380 \mathrm{~m}$ altitude from where the meltwater stream (river Chaturangi) emerges (Bisht et al. 2019). The glacier keeps changing because of splitting of ice blocks from the terminus and subsidence at glacier portal (Bisht et al. 2020a). Regional scale precipitation is largely contributed by the ISM as well as IWM (Kumar et al. 2018). At present, glacier comprises all active (joined to main trunk) tributary glaciers (Suralaya, Vashuki, Seeta 

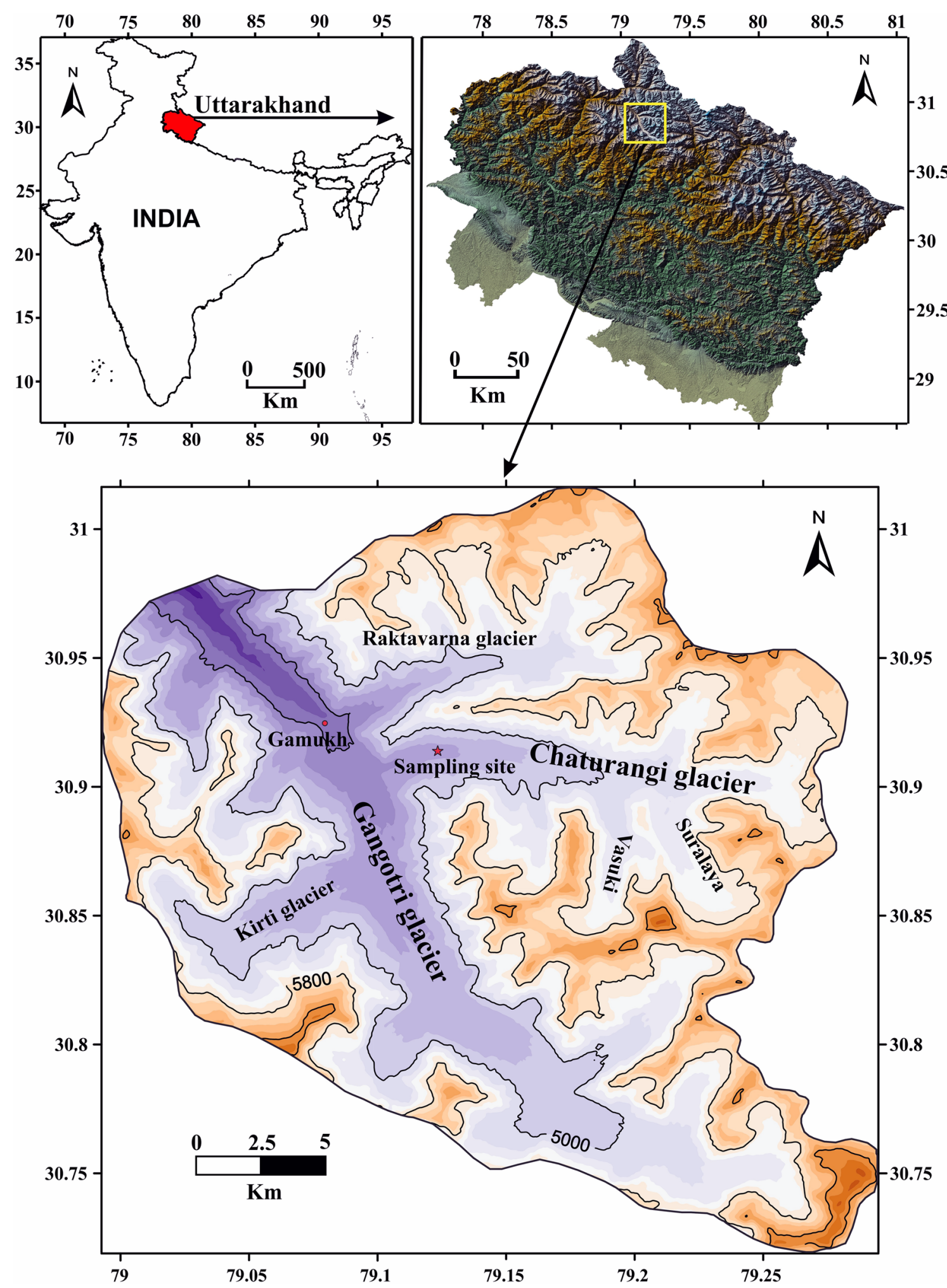

Fig. 1 Map of the study area with location of sampling site

etc.). The ablation zone is partially covered by the sediment, transported by erosion of the valley walls on the glacier surface. In this zone, the transverse and longitudinal crevasses
(Fig. 2b) and the supraglacial lakes (Fig. 2c) were observed on the glacier surface.

Geologically, catchment of the Chaturangi glacier lies above the Main Central Thrust (MCT). Rocks of this area 


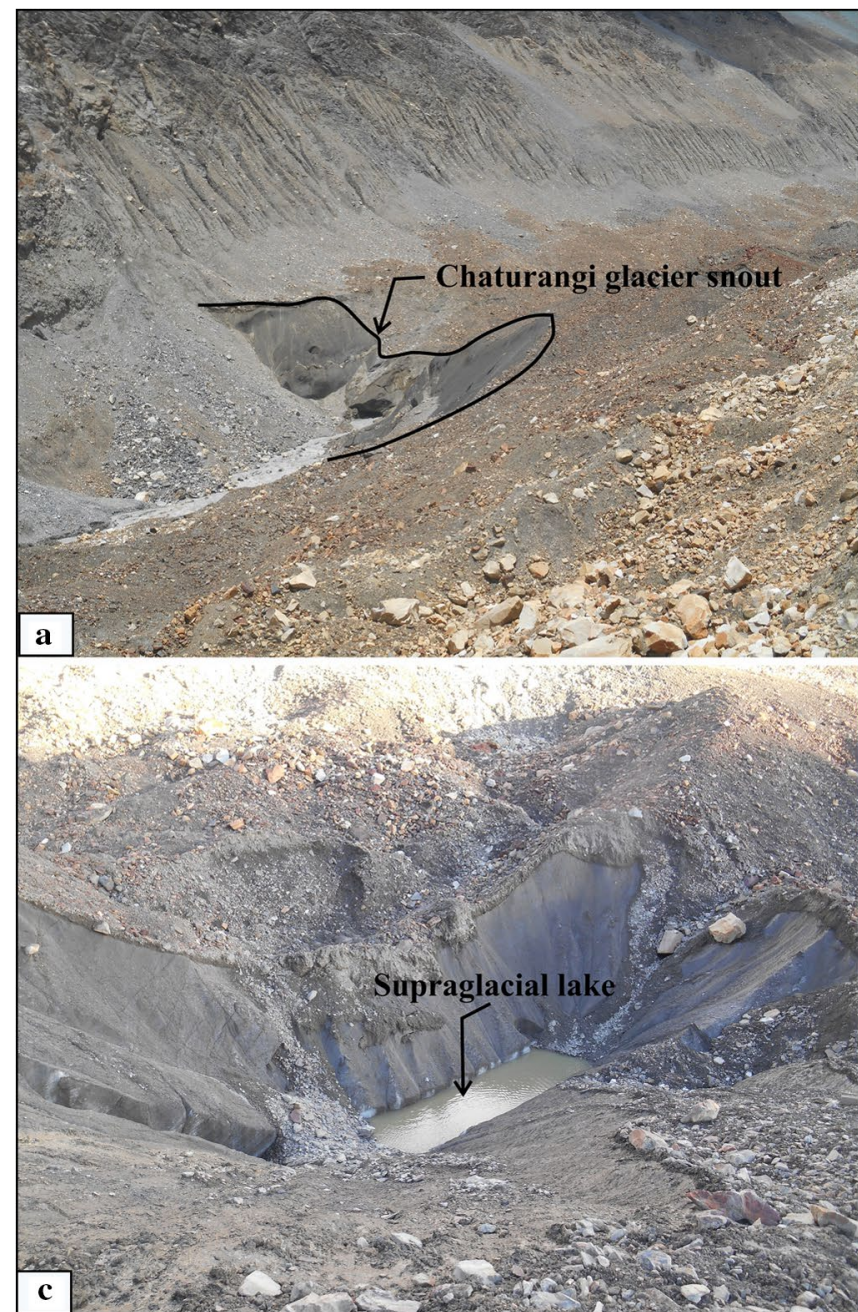

Fig. 2 Field photographs a Snout of the Chaturangi glacier from which Chaturangi river originates. b Transverse and longitudinal crevasses on the surface of glacier. c Supraglacial lake on top of the

are mainly composed of the Higher Himalaya crystalline sequence (HHC) and Lesser Himalayan sequence (LHS), comprising mainly of Vaikrita group of gneisses, Harsil (meta) sediments, tourmaline leucogranite, Bhairongathi granite and Martoli formation (meta) sediments (Fig. 3). The granite rock is mainly composed of alkali feldspar, quartz, muscovite, biotite and crystals of tourmaline. The gneiss of this area is intruded by the granite which forms granitic gneiss. The Jhala normal fault passes from the study area, separating Harsil metasedimentary rocks from quartzo-feldpathic sillimanite gneiss (Searle et al. 1999). The neotectonic activity is major mechanism for geomorphic evolution of this area (Bali et al. 2003), and nearby landform is integrated outcome of glacio-tectonic movements and weathering processes (Bisht et al. 2020a).

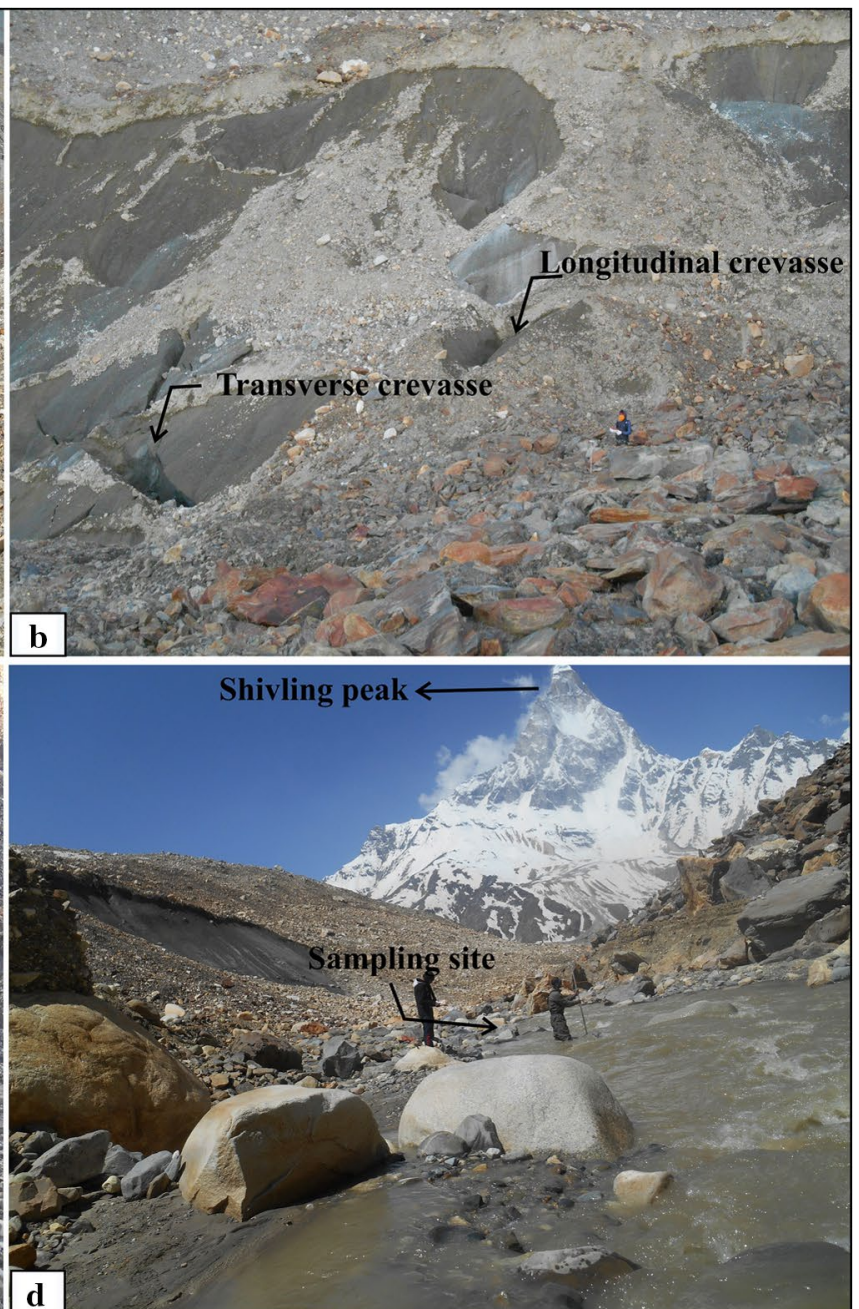

Chaturangi glacier. d Sampling site for the collection of water samples and discharge measurement

\section{Methodology}

\section{Sample collection}

The water sampling site for glacier meltwater was selected around $0.5 \mathrm{~km}$ downstream from present snout position (Figs. 1 and 2d). A total of 118 samples in 2015 and 122 samples in 2016 were collected in $500 \mathrm{ml}$ plastic bottles in both ablation periods from June to September. The samples were collected following Ostrem (1975) and analyzed in the Water Processing and Management (WPM) laboratory of G. B. Pant National Institute, Kosi-Katarmal Almora, Uttarakhand. Additionally, fresh rock samples were also collected from near the glacier catchment to 


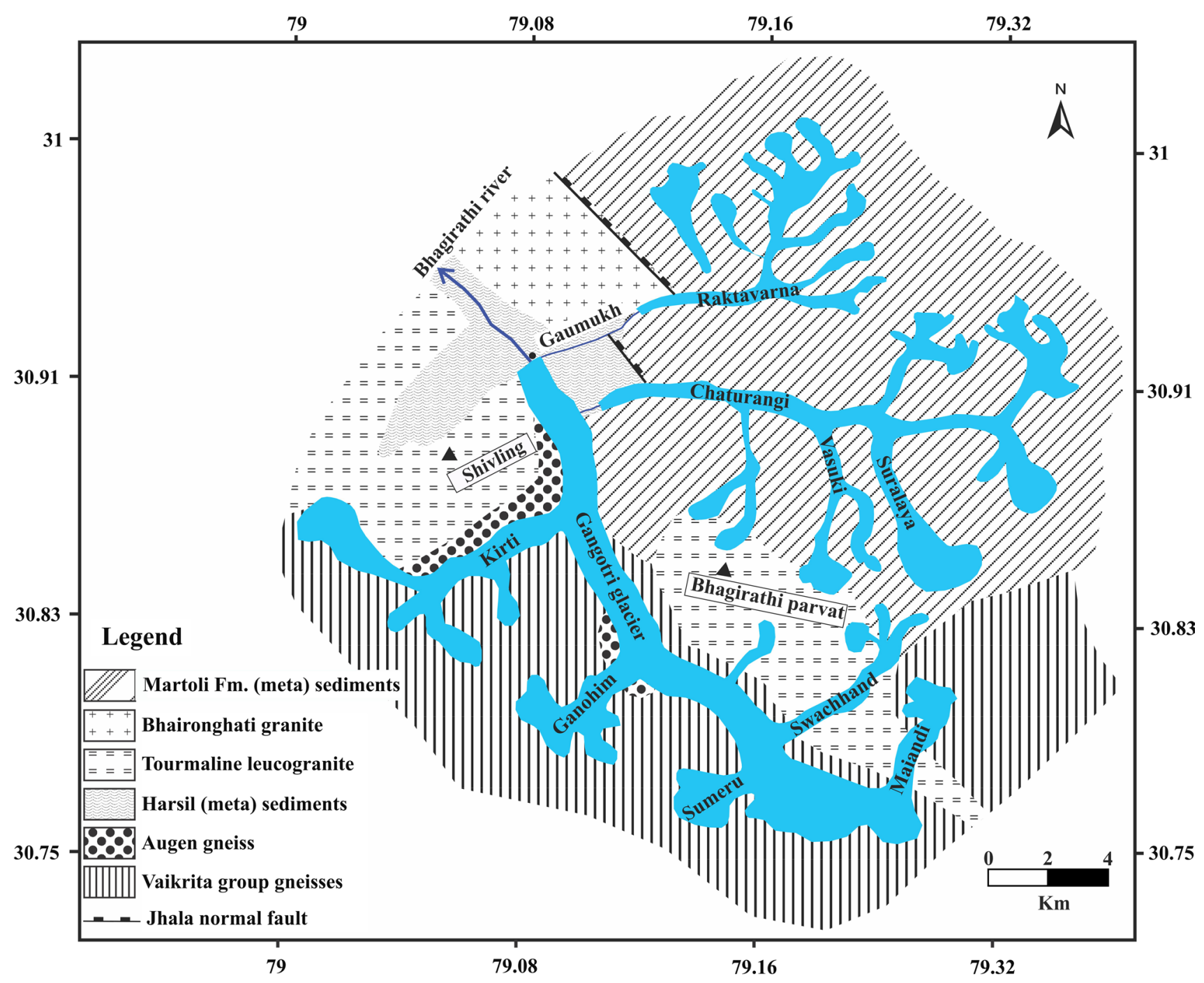

Fig. 3 A simplified geological map of the upper reaches of Bhagirathi basin close to the glacier (modified after Searle et al. 1999)

identify mineral assemblages that contribute ions into the glacier melt.

\section{Onsite measurements}

Onsite analyses of potential of hydrogen $(\mathrm{pH})$, electrical conductivity (EC) and total dissolved solids (TDS) of glacier meltwater were carried out using APHA 2005 method. The TDS was analyzed by a portable instrument (PCS tester 35 ) and the EC and pH were measured using New Professional Trimeter. The total discharge of the meltwater was calculated in the field by using area velocity method (Eq. 1). The area of channel cross section and velocity of flow were estimated using surveying technique as explained by Hubbard and Glassar (2005). In this technique, measuring tape and sounding rod were used, and the cross-sectional area of the channel was measured with the help of plotting values of water depth across the channel of the stream at every $50 \mathrm{~cm}$ interval on a graph. To estimate the flow velocity of channel, wooden floats were used and the time traveled by the float to cover a $10 \mathrm{~m}$ distance was recorded through stopwatch. To minimizing the error in the flow velocity, channel was divided into three segments and the velocity measurement process was repeated three times for each segment. Since velocity of stream decreases exponentially toward the river bank and the bed, the correction factor $(k=0.8)$ was applied to obtain the mean channel velocity. The discharge $(Q)$ was estimated using the Eq. 1 (Hubbard and Glassar 2005).

$Q=k(A \times V)$

where $Q$ is discharge of meltwater, $A$ is area of channel cross section, $k$ is velocity correction factor $(0.8)$ for mean velocity of the channel and $V$ is velocity of surface water flow. 


\section{Laboratory measurements}

\section{Hydrogeochemical analysis}

The hydrogeochemical analysis was carried out with a regular method (APHA 2005). Sodium $\left(\mathrm{Na}^{+}\right)$and potassium $\left(\mathrm{K}^{+}\right)$ values were obtained with the help of Flame Photometer (Systronics flame photometer 128). Magnesium $\left(\mathrm{Mg}^{2+}\right)$ and calcium $\left(\mathrm{Ca}^{2+}\right)$ were analyzed by EDTA titration and the chloride $\left(\mathrm{Cl}^{-}\right)$and Bicarbonate $\left(\mathrm{HCO}_{3}^{-}\right)$by acid titration method. The sulfate $\left(\mathrm{SO}_{4}{ }^{2-}\right)$ and fluoride $\left(\mathrm{F}^{-}\right)$values were obtained through photometer (Paqualb photometer 5000) and spectrophotometer (Eppendorf AG 22,331), respectively. For plotting the piper graph Rock Ware, Inc. AqQA software was applied. The SPSS software version 10.5 was used for statistical analysis.

\section{Petrographic analysis}

As mentioned in the text, the bedrock of catchment area comprises of granites, gneisses, schist and metasediments. Thin sections of four rock samples were prepared for petrographic analysis under transmitted light in petrographic microscope. In addition, the mineral assemblages were studied by point counting technique, in which a total of 500 points were taken for every slide using Gazzi-Dickinson method (Gazzi 1966; Dickinson 1970).

Water quality indexing method To calculate the Water Quality Index (WQI), a total of nine parameters ( $\mathrm{pH}, \mathrm{EC}$, TDS, $\mathrm{Ca}^{2+}, \mathrm{Mg}^{2+}, \mathrm{Na}^{+}, \mathrm{SO}_{4}{ }^{2-}, \mathrm{Cl}^{-}$and $\mathrm{F}^{-}$) were selected (Tables 1 and 2). The WQI was compared using standards of drinking water quality given by Bureau of Indian Standards (BIS) that
Table 1 Estimation process of Water quality index through the help of different physicochemical parameters with drinking water standards of Bureau of Indian Standard and computed average concentration values during the year 2015
Table 2 Estimation process of Water quality index through the help of different physicochemical parameters with drinking water standards of Bureau of Indian Standard and computed average concentration values during the year 2016

\begin{tabular}{lllllccrr}
\hline Parameters (mg/L) & $\begin{array}{l}\text { BIS stand- } \\
\text { ards (Sn) }\end{array}$ & $k$ & $W n$ & $\begin{array}{l}\text { Ideal } \\
\text { value } \\
(\text { Vo) }\end{array}$ & $\begin{array}{l}\text { Measured } \\
\text { value }(\text { Vn })\end{array}$ & Vn/Sn & Qn & Wn $\times$ Qn \\
\hline pH & 8.5 & 0.845 & 0.099 & 7 & 5.5 & 1 & 100 & 9.945 \\
EC & 300 & 0.845 & 0.003 & 0 & 173.6 & 0.579 & 57.867 & 0.163 \\
TDS & 500 & 0.845 & 0.002 & 0 & 89.82 & 0.180 & 17.964 & 0.030 \\
Calcium & 300 & 0.845 & 0.003 & 0 & 11 & 0.037 & 3.667 & 0.010 \\
Magnesium & 75 & 0.845 & 0.011 & 0 & 10.8 & 0.144 & 14.4 & 0.162 \\
Sodium & 200 & 0.845 & 0.004 & 0 & 9.2 & 0.046 & 4.6 & 0.019 \\
Sulphate & 30 & 0.845 & 0.028 & 0 & 38.88 & 1.296 & 129.6 & 3.652 \\
Chloride & 200 & 0.845 & 0.004 & 0 & 2.8 & 0.014 & 1.4 & 0.006 \\
Fluoride & 1 & 0.845 & 0.845 & 0 & 0.38 & 0.38 & 38 & 32.122 \\
$\Sigma$ & & & & & & & & $\mathbf{4 6 . 1 1 0}$ \\
\hline
\end{tabular}

The bold value showing the sum of all the parameters which indicates the water quality index value for the years 2015 and 2016 respectively. On the basis of these values, we can determine the status of water quality by using the ranges given in Table 3

\begin{tabular}{lllllcccc}
\hline Parameters (mg/L) & $\begin{array}{l}\text { BIS stand- } \\
\text { ards (Sn) }\end{array}$ & $k$ & $W n$ & $\begin{array}{l}\text { Ideal } \\
\text { value } \\
(V o)\end{array}$ & $\begin{array}{l}\text { Measured } \\
\text { value }(V n)\end{array}$ & $V n / S n$ & $Q n$ & $W n \times Q n$ \\
\hline $\mathrm{pH}$ & 8.5 & 0.845 & 0.099 & 7 & 5.81 & 0.79 & 79 & 7.856 \\
$\mathrm{EC}$ & 300 & 0.845 & 0.002 & 0 & 157.3 & 0.524 & 52.433 & 0.147 \\
TDS & 500 & 0.845 & 0.001 & 0 & 81.12 & 0.162 & 16.224 & 0.027 \\
Calcium & 300 & 0.845 & 0.002 & 0 & 9.6 & 0.032 & 3.2 & 0.009 \\
Magnesium & 75 & 0.845 & 0.011 & 0 & 2.76 & 0.037 & 3.68 & 0.041 \\
Sodium & 200 & 0.845 & 0.004 & 0 & 5.6 & 0.028 & 2.8 & 0.011 \\
Sulphate & 30 & 0.845 & 0.028 & 0 & 26.88 & 0.896 & 89.6 & 2.524 \\
Chloride & 200 & 0.845 & 0.004 & 0 & 3.85 & 0.019 & 1.925 & 0.008 \\
Fluoride & 1 & 0.845 & 0.845 & 0 & 0.29 & 0.29 & 29 & 24.514 \\
$\Sigma$ & & & & & & & & $\mathbf{3 5 . 1 4 1}$ \\
\hline
\end{tabular}

The bold value showing the sum of all the parameters which indicates the water quality index value for the years 2015 and 2016 respectively. On the basis of these values, we can determine the status of water quality by using the ranges given in Table 3 
has been widely used to determine the water quality (Adimalla et al. 2020; Adimalla and Taloor 2020; Taloor et al. 2020). GIS is very useful for making decisions on the basis of spatial data that have been collected through remote sensing and field sampling. The GIS helps in mapping of hazard zones for pollution in water bodies. Although a combined use of GPS and GIS may help natural resource planners to develop management actions for various natural resource management applications. Our study on water quality is for a limited area on the basis of different parameters as mentioned above. The Weighted Arithmetic Index method given by Brown et al (1972) was used for calculation of WQI (Eq. 2).

$\mathrm{WQI}=\sum_{i=0}^{n} \frac{W i q i}{W i}$

where $q i=$ quality rating or sub index for the $i$ th parameter and $W i=$ unit weight for the $i$ th parameter.

The WQI was calculated using following steps; calculation of quality rating or sub index ( $q i)$, is expressed as:

$q i=\left(\frac{(V a-V i)}{(V s-V i)}\right) \times 100$

where $V a=$ measured value of the $i$ th parameter of water sample, $V s=$ Standard value of $i$ th parameter and $V i=$ ideal value of $i$ th parameter (ideal value is 0 for the all parameters except $\mathrm{pH}(7.0)$ and $\mathrm{DO}(14.6 \mathrm{mg} / \mathrm{L})$.

Calculation of unit weight $(\mathrm{Wi})$ for ith parameter is expressed as:

$W i=\frac{k}{S i}$

where $k$ is the proportionality constant and $S i=$ standard permissible limit of $i$ th parameter.

Further, calculation of proportionality constant is calculated as:

$k=\frac{1}{\sum \frac{1}{S i}}$

Using these parameters, the categorization of calculated WQI values for water quality into five different classes is given in Table 3.

Table 3 Water quality index ranges and their designations developed by Brown et al (1972)

\begin{tabular}{ll}
\hline Water quality index & Water quality status \\
\hline $0-25$ & Excellent \\
$26-50$ & Good \\
$51-75$ & Poor \\
$76-100$ & Very poor \\
$>100$ & Unfit for consumption \\
\hline
\end{tabular}

\section{Result and discussions}

\section{Hydrogeochemistry of glacier meltwater}

To determine the concentration of ions and role of weathering process in solute dynamics, various physical and chemical parameters of meltwater with minimum, maximum, average and standard deviation (STDEV) are shown in Table 4. The $\mathrm{pH}$ values of the meltwater ranges between 3.97 and 6.06 (average $5.5 \pm 0.55$ ) for 2015 and 4.61-6.32 (mean 5.81 \pm 0.4 ) for 2016 (Table 4), showing that it is slightly acidic. The electrical conductivity (EC) of meltwater ranges between 123.6 and $194.7 \mu \mathrm{S} /$ $\mathrm{cm}$ (average $173.6 \pm 21.74 \mu \mathrm{S} / \mathrm{cm}$ ) for the year 2015 and $118.52-191.9 \mu \mathrm{S} / \mathrm{cm}$ (average $157.3 \pm 9.33 \mu \mathrm{S} / \mathrm{cm}$ ) for the year 2016 (Table 4). The EC mainly depends on the concentration of total dissolved solids (TDS) (Singh et al. 2015; Bisht et al. 2017) and the TDS is generally considered as ionic potential of the solution (Sharma et al. 2013). The TDS in meltwater varies from 63.36 to $101.05 \mathrm{mg} / \mathrm{L}$ (average $89.82 \pm 11.53 \mathrm{mg} / \mathrm{L}$ ) in 2015 and $59.54-99.55 \mathrm{mg} / \mathrm{L}$ (average $81.12 \pm 4.97 \mathrm{mg} / \mathrm{L}$ ) in 2016 . High variability in EC also shows that the hydrogeochemistry of catchment is mainly influenced by rock-water interaction and meteorological parameters (Kumar et al. 2018). Our results show higher values of TDS and EC during the ablation season in 2015, compared to that in 2016. This is due to lower values of discharge in 2015 than in 2016 (Tables 5, 6) as high concentration of dissolved ion are occurred due to high time period and longer contact of meltwater with basal lithology during low discharge period (Singh et al. 2014a; Bisht et al. 2017). Singh et al. (2014a) suggested that the lower discharge values increase the TDS concentration, whereas the higher discharge dilutes the TDS of the meltwater. Thomas et al (2015) also suggested that the lower values of EC in glacier meltwater are due to rising discharge through precipitation. Therefore, the results derived from the present study are in concurrence with the previous studies.

The cationic concentration of meltwater indicates that the average concentration of $\mathrm{Ca}^{2+}, \mathrm{Mg}^{2+}, \mathrm{Na}^{+}$and $\mathrm{K}^{+}$was $11 \pm 3.24,10.8 \pm 4.07,9.2 \pm 4.67$ and $5.85 \pm 1.12 \mathrm{mg} / \mathrm{L}$, respectively in year 2015 and $9.6 \pm 4.12,2.76 \pm 1.26$, $5.6 \pm 3.4$ and $3.12 \pm 1.15$, respectively in year 2016 . Similarly the average anionic concentration of meltwater indicate that the average concentration of $\mathrm{HCO}_{3}{ }^{-}$, $\mathrm{SO}_{4}{ }^{2-}, \mathrm{Cl}^{-}$and $\mathrm{F}^{-}$was $188.49 \pm 12.6,38.88 \pm 4.6$, $2.8 \pm 1.29$ and $0.38 \pm 0.16 \mathrm{mg} / \mathrm{L}$, respectively in year 2015 and $129.88 \pm 18.82,26.88 \pm 1.95,3.85 \pm 0.7$ and $0.29 \pm 0.1 \mathrm{mg} / \mathrm{L}$, respectively in year 2016 . This indicates that $\mathrm{Ca}^{2+}$ is dominant cation in the meltwater followed by $\mathrm{Mg}^{2+}, \mathrm{Na}^{+}$and $\mathrm{K}^{+}$which contribute $29.87 \%, 29.31 \%$, 
Table 4 Physicochemical parameters and ionic concentration ratios of Chaturangi glacier meltwater during the entire ablation season in year 2015 and 2016

\begin{tabular}{|c|c|c|c|c|c|c|c|c|}
\hline \multirow[t]{2}{*}{ Parameters } & \multicolumn{4}{|c|}{$2015(n=118)$} & \multicolumn{4}{|c|}{$2016(n=122)$} \\
\hline & $\operatorname{Max}$ & Min & Avg & STDEV & $\operatorname{Max}$ & Min & Avg & STDEV \\
\hline $\mathrm{EC}$ & 194.7 & 123.6 & 173.6 & 21.74 & 191.9 & 118.52 & 157.3 & 9.33 \\
\hline $\mathrm{pH}$ & 6.06 & 3.97 & 5.5 & 0.55 & 6.32 & 4.61 & 5.81 & 0.4 \\
\hline TDS & 101.05 & 63.36 & 89.82 & 11.53 & 99.55 & 59.54 & 81.12 & 4.97 \\
\hline $\mathrm{Ca}^{2+}$ & 18.2 & 6.4 & 11 & 3.24 & 19 & 3.8 & 9.6 & 4.12 \\
\hline $\mathrm{Mg}^{2+}$ & 21.12 & 6.72 & 10.8 & 4.07 & 5.64 & 0.6 & 2.76 & 1.26 \\
\hline $\mathrm{Na}^{+}$ & 23 & 4.6 & 9.2 & 4.67 & 18.4 & 2.07 & 5.6 & 3.4 \\
\hline $\mathrm{K}^{+}$ & 7.41 & 3.35 & 5.85 & 1.12 & 6.24 & 1.56 & 3.12 & 1.15 \\
\hline $\mathrm{F}^{-}$ & 0.95 & 0.19 & 0.38 & 0.16 & 0.87 & 0.22 & 0.29 & 0.1 \\
\hline $\mathrm{Cl}^{-}$ & 7 & 1.75 & 2.8 & 1.29 & 5.25 & 2.45 & 3.85 & 0.7 \\
\hline $\mathrm{SO}_{4}^{2-}$ & 52.32 & 33.6 & 38.88 & 4.6 & 29.76 & 20.64 & 26.88 & 1.95 \\
\hline $\mathrm{HCO}_{3}^{-}$ & 237.29 & 176.9 & 188.49 & 12.6 & 170 & 102 & 129.88 & 18.82 \\
\hline$(\mathrm{Ca}+\mathrm{Mg}) /(\mathrm{Na}+\mathrm{K})$ & 1.83 & 1.09 & 1.47 & 0.14 & 2.31 & 0.86 & 1.44 & 0.28 \\
\hline$(\mathrm{Na}+\mathrm{K}) / \mathrm{TZ}^{+}$ & 0.48 & 0.35 & 0.41 & 0.02 & 0.41 & 0.13 & 0.22 & 0.05 \\
\hline$(\mathrm{Ca}+\mathrm{Mg}) / \mathrm{TZ}^{+}$ & 0.65 & 0.52 & 0.59 & 0.02 & 0.7 & 0.46 & 0.58 & 0.04 \\
\hline $\mathrm{K} / \mathrm{Cl}$ & 3.96 & 1.02 & 2.29 & 0.62 & 1.3 & 0.44 & 0.8 & 0.2 \\
\hline $\mathrm{Na} / \mathrm{Cl}$ & 9.25 & 1.64 & 3.36 & 1.29 & 3.56 & 0.64 & 1.39 & 0.6 \\
\hline$C$-Ratio & 0.84 & 0.81 & 0.83 & 0.009 & 0.85 & 0.8 & 0.83 & 0.01 \\
\hline$S$-Ratio & 0.19 & 0.16 & 0.17 & 0.009 & 0.2 & 0.15 & 0.17 & 0.02 \\
\hline $\mathrm{Ca} / \mathrm{Na}$ & 1.95 & 0.76 & 1.31 & 0.27 & 3 & 0.95 & 1.83 & 0.37 \\
\hline $\mathrm{Mg} / \mathrm{Na}$ & 1.91 & 0.82 & 1.25 & 0.21 & 1.01 & 0.25 & 0.54 & 0.19 \\
\hline $\mathrm{HCO}_{3} / \mathrm{Na}$ & 38.89 & 9.37 & 24.69 & 9.05 & 49.46 & 9.1 & 28.31 & 9.84 \\
\hline
\end{tabular}

Unit: all parameters are in $\mathrm{mg} / \mathrm{l}$ except the $\mathrm{EC}$ and $\mathrm{pH}, \mathrm{EC}$ in $\mu \mathrm{S} / \mathrm{cm}$

Table 5 Estimation of daily and entire ablation periods Individual Ion Flux (IIF), cation flux $\left(\mathrm{F}^{+}\right)$, anion flux $\left(\mathrm{F}^{-}\right)$, cation denudation rate $\left(\mathrm{R}^{+}\right)$ and anion denudation rate $\left(\mathrm{R}^{-}\right)$of the Chaturangi glacier catchment in year 2015

\begin{tabular}{|c|c|c|c|c|c|c|c|c|c|}
\hline & \multicolumn{9}{|c|}{ Analytes (ton) } \\
\hline & $\mathrm{Ca}^{2+}$ & $\mathrm{Mg}^{2+}$ & $\mathrm{Na}^{+}$ & $\mathrm{K}^{+}$ & $\mathrm{F}^{-}$ & $\mathrm{Cl}^{-}$ & $\mathrm{SO}_{4}^{-2}$ & $\mathrm{HCO}_{3}^{-}$ & Total \\
\hline IIF (ton day ${ }^{-1}$ ) & 17.84 & 17.52 & 14.92 & 9.48 & 0.61 & 4.54 & 63.06 & 305.73 & 433.73 \\
\hline IIF (ablation period) & 2105.39 & 2067.11 & 1760.87 & 1119.69 & 72.73 & 535.92 & 7441.61 & $36,076.86$ & $51,180.18$ \\
\hline $\mathrm{Fx}^{+}\left(\right.$ton day $\left.{ }^{-1}\right)$ & & 59.76 & & & & & & & \\
\hline $\mathrm{Fx}^{+}$(ablation period) & & 7053.06 & & & & & & & \\
\hline $\mathrm{Fx}^{-}\left(\right.$ton $\left.\mathrm{day}^{-1}\right)$ & & & & & & 373.94 & & & \\
\hline $\mathrm{Fx}^{-}$(ablation period) & & & & & & $44,127.12$ & & & \\
\hline $\mathrm{R}^{+}\left(\right.$ton $\mathrm{km}^{-2}$ day $\left.^{-1}\right)$ & & 0.28 & & & & & & & \\
\hline $\mathrm{R}^{+}$(ablation period) & & 32.84 & & & & & & & \\
\hline $\mathrm{R}^{-}\left(\right.$ton $\mathrm{km}^{-2}$ day $\left.^{-1}\right)$ & & & & & & 1.74 & & & \\
\hline $\mathrm{R}^{-}$(ablation period) & & & & & & 205.43 & & & \\
\hline Water discharge & \multicolumn{9}{|c|}{$1.62 \times 10^{9} \mathrm{~L}$ per day; $1.91 \times 10^{11} \mathrm{~L}$ during entire ablation period } \\
\hline \multicolumn{10}{|c|}{ *Catchment Area $\left(214.80 \mathrm{~km}^{2}\right)$} \\
\hline
\end{tabular}

Ablaiton period, 5th June to 30th September (118 days); *Data taken from (Orr et al. 2019)

$24.96 \%$, and $15.86 \%$ of the total cations, respectively in year 2015, while $\mathrm{Ca}^{2+}$ is most dominant cation followed by $\mathrm{Na}^{+}, \mathrm{K}^{+}$and $\mathrm{Mg}^{2+}$, contributing $45.54 \%, 26.55 \%$, $14.82 \%$, and $13.09 \%$ of the total cations, respectively in year 2016. Among the anions, $\mathrm{HCO}_{3}{ }^{-}$is leading anion followed by $\mathrm{SO}_{4}{ }^{2-}, \mathrm{Cl}^{-}$and $\mathrm{F}^{-}$which contribute $81.75 \%$, $16.86 \%, 1.22 \%$, and $0.17 \%$ of the total anions, respectively in 2015 and $80.72 \%, 16.71 \%, 2.39 \%$, and $0.18 \%$ of total anions, respectively in 2016 . 
Table 6 Estimation of daily and entire ablation periods Individual Ion Flux (IIF), cation flux $\left(\mathrm{F}^{+}\right)$, anion flux $\left(\mathrm{F}^{-}\right)$, cation denudation rate $\left(\mathrm{R}^{+}\right)$ and anion denudation rate $\left(\mathrm{R}^{-}\right)$of the Chaturangi glacier catchment in year 2016

\begin{tabular}{|c|c|c|c|c|c|c|c|c|c|}
\hline & \multicolumn{9}{|c|}{ Analytes (ton) } \\
\hline & $\mathrm{Ca}^{2+}$ & $\mathrm{Mg}^{2+}$ & $\mathrm{Na}^{+}$ & $\mathrm{K}^{+}$ & $\mathrm{F}^{-}$ & $\mathrm{Cl}^{-}$ & $\mathrm{SO}_{4}^{-2}$ & $\mathrm{HCO}_{3}^{-}$ & Total \\
\hline IIF $\left(\right.$ ton day ${ }^{-1}$ ) & 17.88 & 5.14 & 10.43 & 5.81 & 0.54 & 7.17 & 50.07 & 241.94 & 338.98 \\
\hline IIF (ablation period) & 2181.72 & 627.25 & 1272.67 & 709.06 & 65.91 & 874.96 & 6108.83 & $29,516.93$ & $41,357.33$ \\
\hline $\mathrm{Fx}^{+}\left(\right.$ton day $\left.{ }^{-1}\right)$ & & 39.26 & & & & & & & \\
\hline $\mathrm{Fx}^{+}$(ablation period) & & 4790.70 & & & & & & & \\
\hline $\mathrm{Fx}^{-}\left(\right.$ton day $\left.{ }^{-1}\right)$ & & & & & & 299.72 & & & \\
\hline $\mathrm{Fx}^{-}$(ablation period) & & & & & & $36,566.63$ & & & \\
\hline $\mathrm{R}^{+}\left(\right.$ton $\mathrm{km}^{-2}$ day $\left.^{-1}\right)$ & & 0.18 & & & & & & & \\
\hline $\mathrm{R}^{+}$(ablation period) & & 22.30 & & & & & & & \\
\hline $\mathrm{R}^{-}\left(\right.$ton $\mathrm{km}^{-2}$ day $\left.^{-1}\right)$ & & & & & & 1.40 & & & \\
\hline $\mathrm{R}^{-}$(ablation period) & & & & & & 170.24 & & & \\
\hline $\begin{array}{l}\text { Water discharge } \\
* \text { Catchment Area }(214\end{array}$ & \multicolumn{9}{|c|}{$\begin{array}{l}1.86 \times 10^{9} \mathrm{~L} \text { per day; } 2.27 \times 10^{11} \mathrm{~L} \text { during entire ablation period } \\
\mathrm{km}^{2} \text { ) }\end{array}$} \\
\hline
\end{tabular}

Ablaiton period, 1st June to 30th September (122 days); *Data taken from (Orr et al. 2019)

\section{Solute sources in the meltwater}

Generally the concentration of dissolved ions in glacier meltwater depends on weathering reactions, mineralogy of bedrock, composition and amount of atmospheric inputs and meltwater discharge (Singh and Hasnain 1998). The effect of geology on hydrochemistry of meltwater highly depends on the rock composition, texture, discontinuity and age of the rocks (Lambers et al. 2008; Lintern et al. 2018). When water interacts with the rocks, chemical reaction may occur, leading to decomposition of the rocks and leaching of minerals into the water. This can affect quality of the meltwater either positively or negatively. The rock and soil erodibility as well as capacity of soil absorption can influence mobilization of constituents in the catchments (Lintern et al. 2018). The influence of geology on water quality is indicated by the amount and types of dissolved minerals contributed from a particular area and amount of the sediment load carried through the streams. Lintern et al (2018) reported that ionic constituents in the water, e.g., $\mathrm{Ca}^{2+}, \mathrm{Mg}^{2+}, \mathrm{Na}^{+}, \mathrm{K}^{+}, \mathrm{HCO}_{3}{ }^{-}$, $\mathrm{Cl}^{-}$and minor trace elements are derived due to rock-water interaction. Hence, mineralogy of the adjacent rocks is necessary to better understand the interaction between water and rock, and their role in solute concentration of the meltwater (Bisht et al. 2018). Our petrographic analysis shows that biotite $\left[\mathrm{K}(\mathrm{Mg}, \mathrm{Fe})_{3} \mathrm{AlSi}_{3} \mathrm{O}_{10}(\mathrm{OH})_{2}\right.$ ], alkali feldspar $\left[\mathrm{KAlSi}_{3} \mathrm{O}_{8}\right]$, plagioclase feldspar $\left[\mathrm{NaAlSi}_{3} \mathrm{O}_{8}\right.$ or $\left.\mathrm{CaAl}_{2} \mathrm{Si}_{2} \mathrm{O}_{8}\right]$ and quartz [SiO2] are most abundant minerals in surrounding rocks of metasedimentary composition. The metasediments and biotite granite of the Martoli formation near the snout contain small amount of staurolite $\left[\mathrm{Fe}_{2} \mathrm{Al}_{9} \mathrm{O}_{6}\left(\mathrm{SiO}_{4}\right)_{4}(\mathrm{O}, \mathrm{OH})_{2}\right]$ and garnet $\left[\mathrm{Mg}_{3} \mathrm{Al}_{2} \mathrm{Si}_{3} \mathrm{O}_{12}\right]$ (Fig. 4a-c). The tourmaline [Na(M $\left.\mathrm{g}, \mathrm{Fe})_{3} \mathrm{Al}_{6}\left(\mathrm{BO}_{3}\right)_{3} \mathrm{Si}_{6} \mathrm{O}_{18}(\mathrm{OH})_{4}\right]$, alkali feldspar $\left[\mathrm{KAlSi}_{3} \mathrm{O}_{8}\right]$, plagioclase feldspar $\left[\mathrm{NaAlSi}_{3} \mathrm{O}_{8}\right.$ or $\left.\mathrm{CaAl}_{2} \mathrm{Si}_{2} \mathrm{O}_{8}\right]$ and quartz [SiO2] are the most abundant minerals in tourmaline leucogranite lithotype (Fig. 4d). The results suggest that $\mathrm{K}^{+}$ has definitely entered into the meltwater due to weathering of alkali feldspar and biotite. The $\mathrm{Ca}^{2+}$ contributes in the meltwater because of plagioclase feldspar, while $\mathrm{Na}^{+}$is due to alkali feldspar, plagioclase feldspar and tourmaline. The $\mathrm{Mg}^{2+}$ is added in the meltwater due to weathering of biotite, garnet and tourmaline. Based on the petrographic analysis, we suggest that the cations such as $\mathrm{Ca}^{2+}, \mathrm{Mg}^{2+}, \mathrm{Na}^{+}$and $\mathrm{K}^{+}$ indicate an excellent relationship with mineral abundance of rocks. The hydrogeochemistry controlling mechanism and sources of dissolved ions in glacier meltwater can also be determined through relationship among the ions and their ratios (Sharma et al. 2013; Bisht et al. 2018; Kumar et al. 2019). The scatter plot between $\mathrm{TZ}^{+}$and $(\mathrm{Ca}+\mathrm{Mg})$ (Fig. 5) shows that all of the points fall above 1:1 equiline with mean ratio of $0.59 \pm 0.02$ in 2015 and $0.58 \pm 0.04$ in 2016 (Table 4). Similarly, the $(\mathrm{Ca}+\mathrm{Mg}) /(\mathrm{Na}+\mathrm{K})$ ratios were found as $1.47 \pm 0.14$ in 2015 and $1.44 \pm 0.28$ in 2016 . On the other hand, the scatter graph of $\mathrm{TZ}^{+}$and $\mathrm{Na}+\mathrm{K}$ (Fig. 6) shows most values lie below 1:1 equiline with low ratios $0.41 \pm 0.02$ in 2015 and $0.22 \pm 0.05$ in 2016 (Table 4). The low $\mathrm{Na}+\mathrm{K} / \mathrm{TZ}^{+}$ratios, high $(\mathrm{Ca}+\mathrm{Mg}) /(\mathrm{Na}+\mathrm{K})$ and $\mathrm{Ca}+\mathrm{Mg} / \mathrm{TZ}^{+}$ratios for both the years suggest that the carbonate weathering is foremost mechanism controlling hydrogeochemistry of the Chaturangi glacier meltwater with diminutive contribution by silicate weathering. The scatter plot between $(\mathrm{Ca}+\mathrm{Mg})$ and $\mathrm{SO}_{4}{ }^{2-}$ (Fig. 7) shows most of the values fall above the 1:1 equiline, indicating that $\mathrm{CaSO}_{4}$ and $\mathrm{MgSO}_{4}$ rich rocks are main source for supply of sulphate in the meltwater. Singh et al. (2014b) suggested that oxidation of sulphides could be a second possible source of 


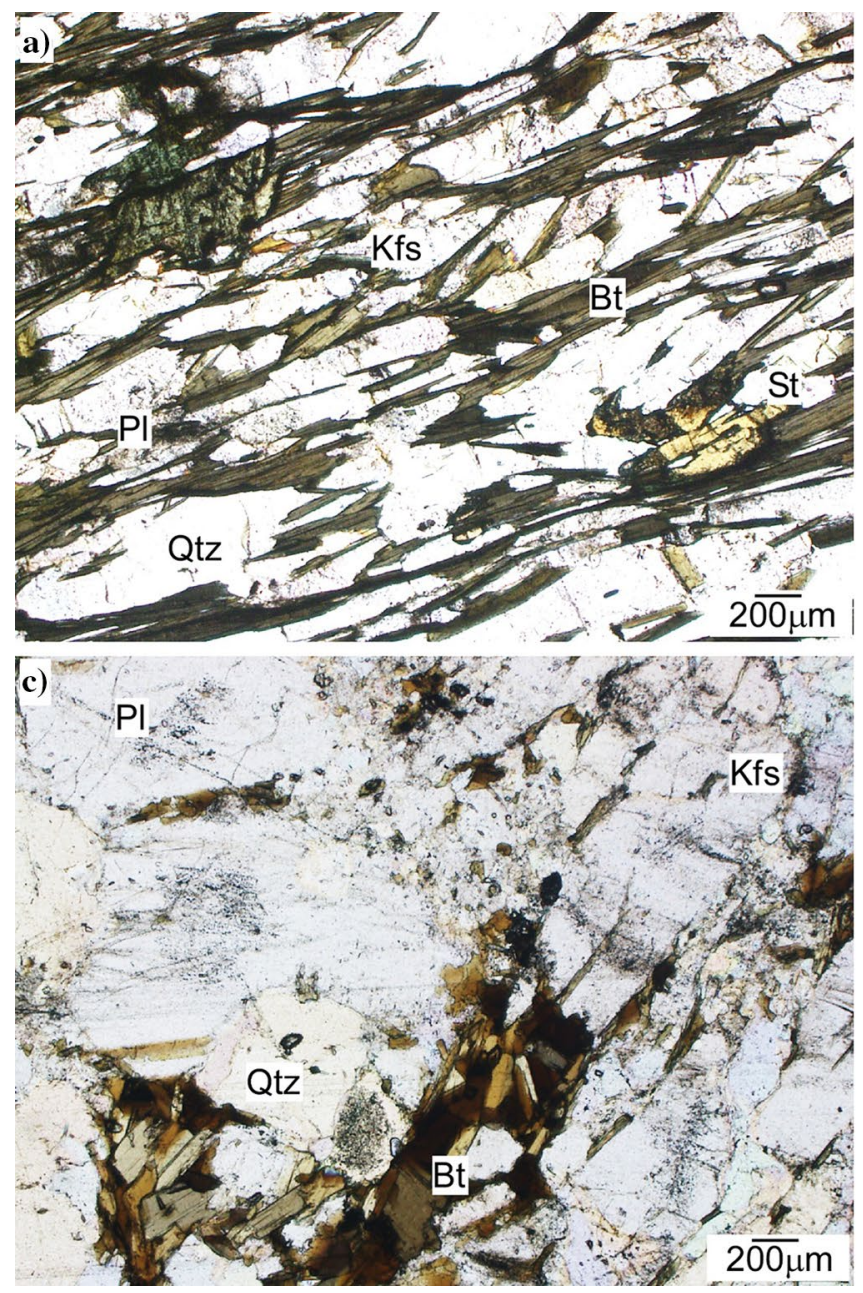

Fig. 4 Microphotographs of the exposed rock types along Chaturangi catchment (a). Harsil metasediment consisting of quartz, alkali feldspar, plagioclase feldspar, biotite and staurolite. (b). Martoli formation metasediments consisting of quartz, alkali feldspar, plagioclase feldspar, biotite and garnet. (c). Biotite granite consisting of quartz,

sulphate in the meltwater. The occurrence of sulphide minerals like pyrite and chalcopyrite with quartz veins of country rocks near glacier snout (Bhatt 1963) shows that oxidation of sulphides is the main sulphate source in the Chaturangi meltwater. The water drained from carbonate rocks demonstrates higher $\mathrm{Mg}^{2+}$ and $\mathrm{Ca}^{2+}$ concentrations, and high ratios of $\mathrm{HCO}_{3} / \mathrm{Na}(120), \mathrm{Ca} / \mathrm{Na}(50)$ and $\mathrm{Mg} / \mathrm{Na}(10)$ (Negrel et al. 1993), whereas, the water drained from silicate rocks demonstrates low ratios of $\mathrm{HCO}_{3} / \mathrm{Na}(2), \mathrm{Ca} / \mathrm{Na}(0.35)$ and $\mathrm{Mg} /$ $\mathrm{Na}(0.24)$ (Gaillardet et al.1999). In meltwater of Chaturangi glacier, we found the ratios of $\mathrm{HCO}_{3} / \mathrm{Na}$ as $24.69 \pm 9.05$ in 2015 and $28.31 \pm 9.84$ in 2016 . We also found the $\mathrm{Ca} /$ $\mathrm{Na}$ ratio as $1.31 \pm 0.27$ in 2015 and $1.83 \pm 0.87$ in 2016 as well as $\mathrm{Mg} / \mathrm{Na}$ as $1.25 \pm 0.21$ in 2015 and $0.54 \pm 0.19$ in 2016. These results show that $\mathrm{Mg} / \mathrm{Na}, \mathrm{Ca} / \mathrm{Na}$ and $\mathrm{HCO}_{3} / \mathrm{Na}$ ratios of meltwater are in accordance that the surrounding
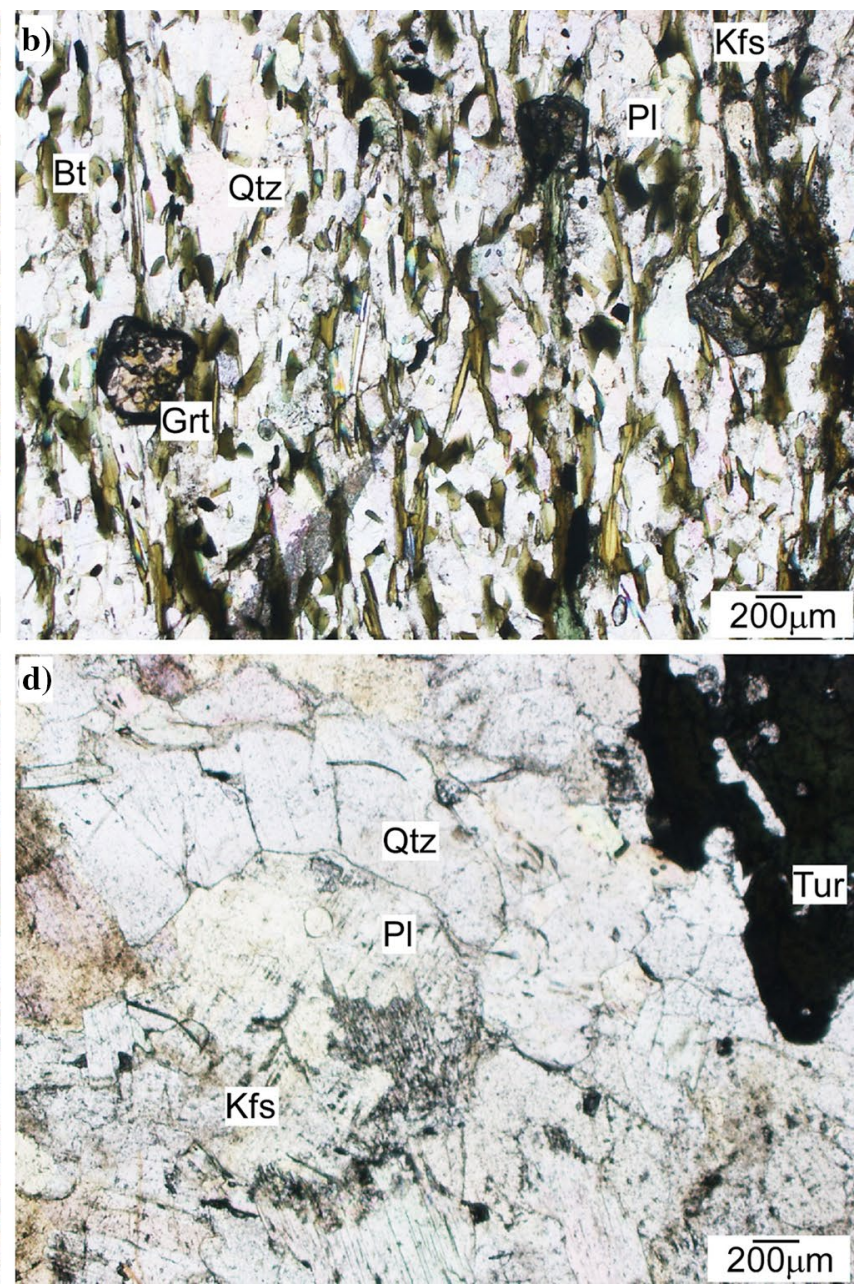

alkali feldspar, plagioclase feldspar and biotite. (d). Tourmaline granite with quartz, alkali feldspar, plagioclase feldspar and tourmaline. Bt- biotite; Grt- garnet; Kfs- alkali feldspar; Pl-plagioclase feldspar; Qtz- quartz; St- staurolite; Tur- tourmaline

lithologies are influencing the hydrogeochemistry of Chaturangi glacier meltwater.

Although rock weathering is main source of solute concentration in the meltwater, the atmospheric precipitation may also have contributed to total dissolved ions (Singh et al. 2014b). A few studies are available on the role of atmospheric input in meltwater chemistry of the glaciers of Central Himalaya (Singh et al. 2014a; Tiwari et al. 2018). It is recognized that the contribution of atmospheric input in the chemistry of meltwater can be best studied by the assessment of element-to-chloride ratios (Kumar et al. 2009). Therefore, in order to determine the contribution of atmospheric input into meltwater chemistry of Chaturangi glacier, the element-to-chloride ratio was studied during the ablation seasons of 2015 and 2016. The scatter graph between $\mathrm{Cl}^{-}$and $\mathrm{Na}+\mathrm{K}$ (Fig. 8) demonstrates that the 
Fig. 5 Scatter plot between total cations and $(\mathrm{Ca}+\mathrm{Mg})$ for Chaturangi glacier meltwater

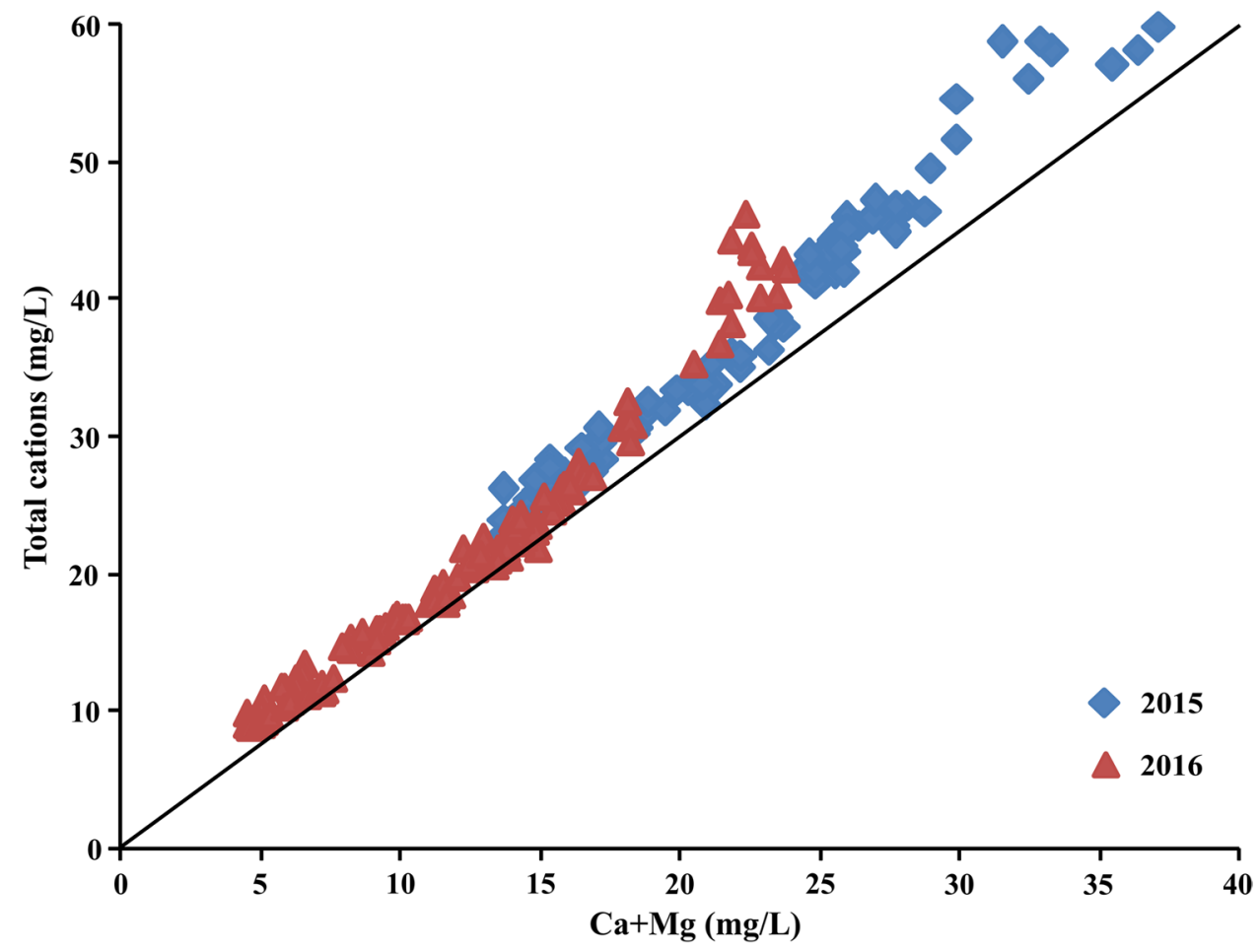

Fig. 6 Scatter plot between total cations and $(\mathrm{Na}+\mathrm{K})$ for glacier meltwater

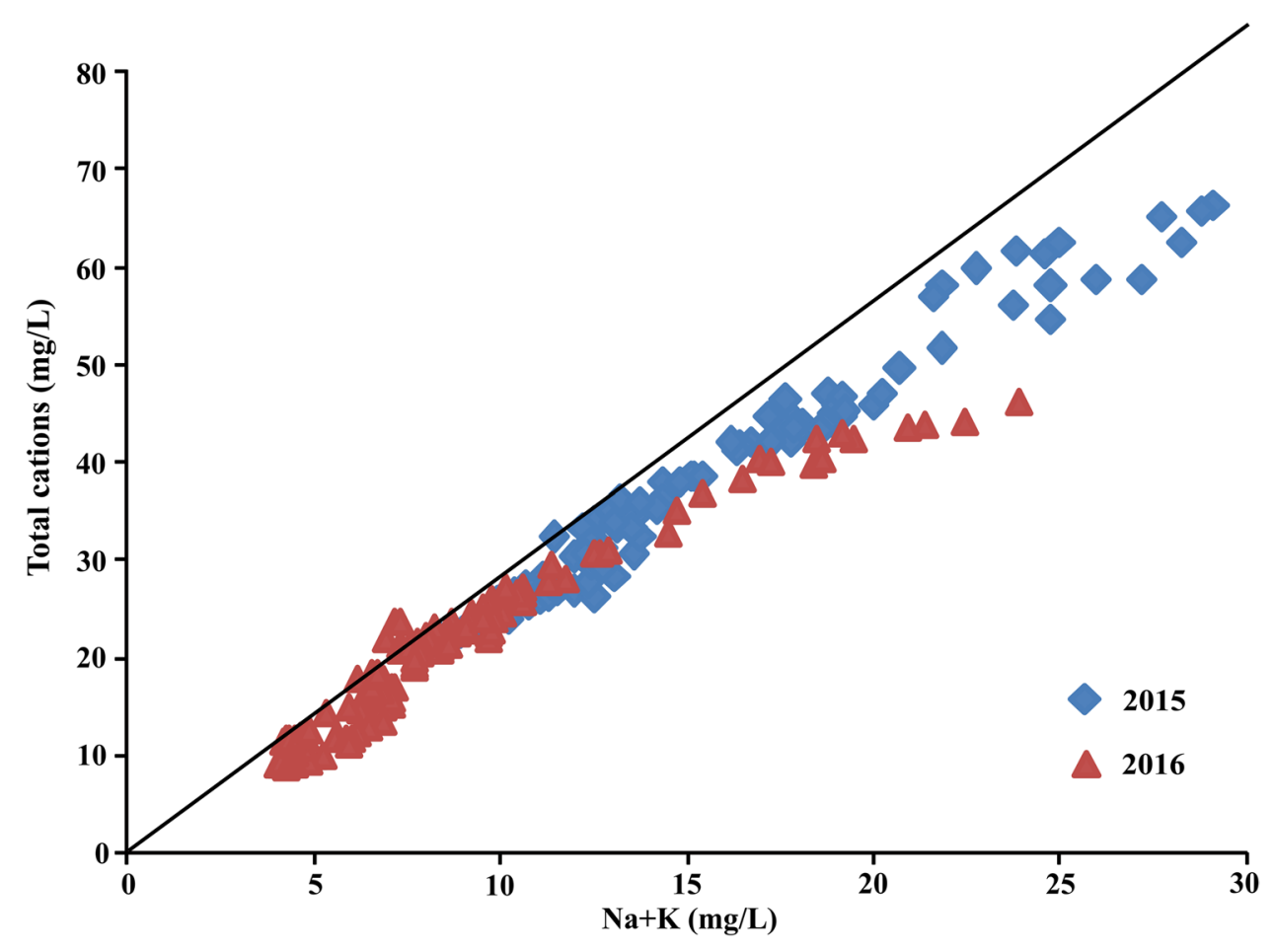

concentration of $\mathrm{Na}+\mathrm{K}$ was greater than chloride in year 2015 , while it was lesser in 2016 . The average $\mathrm{K} / \mathrm{Cl}$ ratios in the Chaturangi meltwater were found as $2.29 \pm 0.62$ in 2015 and $0.8 \pm 0.2$ in 2016, while, the average ratios of $\mathrm{Na} /$ $\mathrm{Cl}$ were $3.36 \pm 1.29$ in 2015 and $1.39 \pm 0.6$ in 2016. The ratios of $\mathrm{Na} / \mathrm{Cl}$ and $\mathrm{K} / \mathrm{Cl}$ are significantly much higher than the marine aerosols (i.e., $\mathrm{Na} / \mathrm{Cl}=0.85$ and $\mathrm{K} / \mathrm{Cl}=0.0176$ ) in 2015 and slightly higher in 2016 (Table 4). For this reason, it clearly indicates comparatively small input of these ions into meltwater from atmosphere in both the years. Furthermore, the results also show relatively high ionic contribution in meltwater from the atmosphere in 2016, 
Fig. 7 Scatter plot between $(\mathrm{Ca}+\mathrm{Mg})$ and $\mathrm{SO}_{4}$ to determine the supply of sulphate in the meltwater
Fig. 8 Scatter plot between $(\mathrm{Na}+\mathrm{K})$ and $\mathrm{Cl}$ to determine the contribution of ions in the meltwater from atmospheric input and other sources
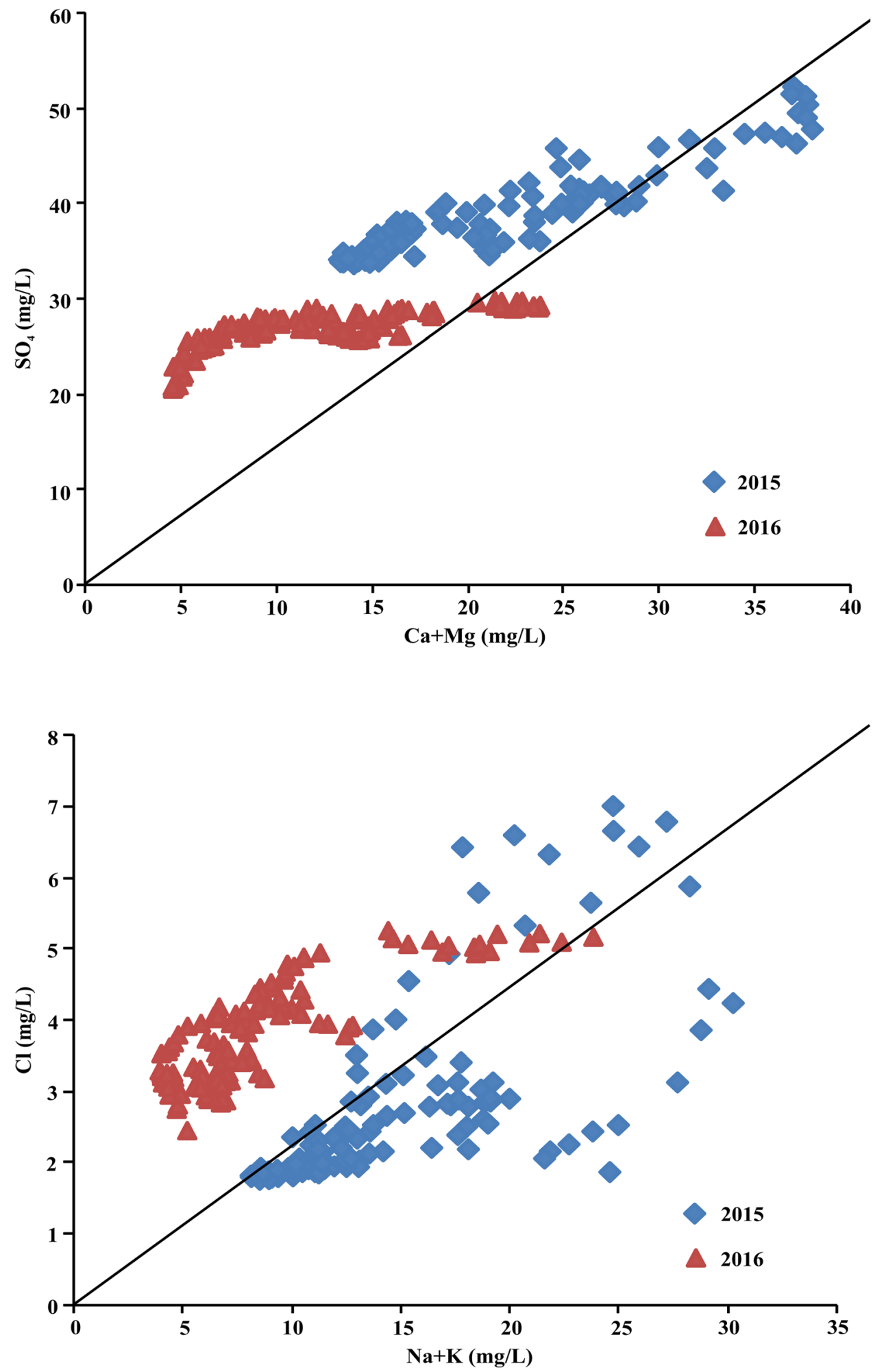

compared to that in 2015. Similar results of low contribution of ions from atmospheric precipitation in the Himalayan glaciers meltwater have also been reported by other workers (Singh et al. 2015, 2019; Singh and Ramanathan 2017; Bisht et al. 2018). It is evident that the major ions, dissolved in the Chaturangi glacier meltwater are mainly controlled by weathering of rocks and associated minerals. The proton source is essential for chemical weathering of the rocks rich in carbonate (Khadka and Ramanathan 2012). In stream waters, the concentration of $\mathrm{SO}_{4}{ }^{2-}$ and 
$\mathrm{HCO}_{3}{ }^{-}$is a sign of domination of two main aqueous proton sources, which drive the sub-glacial weathering reactions (Brown et al. 1996; Hasnain and Thayyen 1999).

$\mathrm{CO}_{2}+\mathrm{H}_{2} \mathrm{O} \rightarrow \mathrm{H}_{2} \mathrm{CO}_{3}$

$\mathrm{H}_{2} \mathrm{CO}_{3} \rightarrow \mathrm{H}^{+}+\mathrm{HCO}_{3}^{-}$

$\mathrm{CaCO}_{3}(\mathrm{~s})+\mathrm{H}_{2} \mathrm{CO}_{3}(\mathrm{aq}) \rightarrow \mathrm{Ca}^{2+}(\mathrm{aq})+2 \mathrm{HCO}_{3}^{-}(\mathrm{aq})$

$4 \mathrm{FeS}_{2}(\mathrm{~s})+16 \mathrm{CaCO}_{3}(\mathrm{~s})+15 \mathrm{O}_{2}(\mathrm{aq})+14 \mathrm{H}_{2} \mathrm{O}(\mathrm{l})$

$\rightarrow 16 \mathrm{Ca}^{2+}(\mathrm{aq})+16 \mathrm{HCO}_{3}^{-}(\mathrm{aq})+8 \mathrm{SO}_{4}^{2-}(\mathrm{aq})$

$+4 \mathrm{Fe}(\mathrm{OH})_{3}(\mathrm{~s})$

The significance of two proton generating reactions, i.e., sulfide oxidation and carbonation are crucial components of weathering of carbonate rocks and this is best explained by $C$-ratio $\left[\left(\mathrm{HCO}_{3} /\left(\mathrm{HCO}_{3}+\mathrm{SO}_{4}\right)\right]\right.$ (Huang et al. 2008). If $C$ ratio is closer to 1 , it symbolizes weathering by carbonation reaction (Eqs. 6-8) and if close to 0.5 , it signifies the two reactions involving sulphide oxidation and carbonate dissolution with protons resulting from the oxidation reaction of pyrite (Eq. 9) (Brown et al. 1996). Similarly, $\mathrm{S}$ ratio $\left[\mathrm{SO}_{4} /\left(\mathrm{SO}_{4}+\mathrm{HCO}_{3}\right)\right]$, close to 0.5 shows weathering by two reactions involving sulphide oxidation and carbonate dissolution, whereas, the ratio near 0 indicates chemical weathering by carbonation reaction (Tranter et al. 1997). Average $C$-ratio for the meltwater of Chaturangi was $0.83 \pm 0.009$ in 2015 and $0.83 \pm 0.01$ in 2016 and this shows that the chemical weathering of this area is controlled mainly by the carbonation reaction. The results also suggest that dissolution of carbonate rocks and disassociation of atmospheric $\mathrm{CO}_{2}$ are responsible for producing protons. Further, the average $S$-ratio as $0.17 \pm 0.009$ in 2015 and $0.10 \pm 0.02$ in 2016 also confirms that the carbonation reaction is mainly responsible for chemical weathering of the surrounding rocks.

For fresh water, the TDS $(\mathrm{mg} / \mathrm{l})$ to $\mathrm{EC}(\mu \mathrm{s} / \mathrm{cm})$ ratio is generally accepted as 0.7 (Meybeck 1984). For meltwater of Chaturangi glacier, average ratio of TDS/ EC was 0.515 in 2015 and 0.517 in 2016, signifying moderately fresh water in nature. In addition, the concentration $\mathrm{F}^{-}$in the meltwater was also observed to determine the quality of meltwater. The average value of $\mathrm{F}^{-}$was $0.38 \pm 0.16 \mathrm{mg} / \mathrm{L}$ in 2015 and $0.29 \pm 0.1 \mathrm{mg} / \mathrm{L}$ in 2016 (Table 1). During both the years, the average $\mathrm{F}^{-}$concentration of meltwater was relatively low as compared to maximum permissible limit $(1.5 \mathrm{mg} / \mathrm{L})$ as per the BIS (1991), showing that the meltwater is suitable for drinking with respect to fluoride contamination. The replacement of ions of crystal lattice of micas and other minerals might be a possible source of $\mathrm{F}^{-}$in the water (Sadat 2012).

\section{Ionic flux and denudation rate of ions}

In this study, we have calculated the ionic flux to the meltwater stream from the streambed and denudation rate of the ions through meltwater from the catchment of Chaturangi glacier throughout the entire ablation seasons in 2015 and 2016. The cationic flux $\left(F x^{+}\right)$and denudation rate of cation $\left(R^{+}\right)$was estimated using the formula (Eqs. 10 and 11) (Fang et al. 2012):

$F x^{+}=\sum_{i=1}^{n} C_{i}^{+}(t) \times Q(t)$

$R^{+}=F x^{+} / m$

where $C_{i}^{+}$is concentration of cations $\left(\mathrm{Ca}^{2+}, \mathrm{Mg}^{2+}, \mathrm{K}^{+}\right.$and $\left.\mathrm{Na}^{+}\right), Q$ is discharge, $t$ is time period and $m$ represents catchment area. Similarly, the anionic flux $\left(F x^{-}\right)$and anion denudation rate $\left(R^{-}\right)$were also calculated.

The ionic flux, ion denudation rate, meltwater discharge of Chaturangi glacier and catchment area during 2015 and 2016 are given in Tables 5 and 6 . The catchment of the glacier covers about $214.8 \mathrm{~km}^{2}$ area (Orr et al. 2019) with an average discharge $1.91 \times 10^{11} \mathrm{~L}$ and $2.27 \times 10^{11} \mathrm{~L}$ for ablation period 2015 and 2016, respectively. The total cationic flux as 59.76 ton per day and 7053.06 ton per ablation season was observed in 2015, whereas, it was measured as 39.26 ton per day and 4790.70 ton per ablation season in 2016. On the other hand, the total anionic flux as 373.94 ton per day and $44,127.12$ ton per ablation season were observed in 2015, whereas 299.72 ton per day and $36,566.63$ ton per ablation period were measured in 2016 . The results show that calcium contributes the highest cationic flux as $29.85 \%$ and $45.54 \%$ of total cations in 2015 and 2016 respectively, as well as the bicarbonate contribute highest anionic flux as $81.76 \%$ and $80.72 \%$ of total anions in 2015 and 2016, respectively. In addition, the cation denudation rate as 0.28 ton/ $/ \mathrm{km}^{2} /$ day and 32.84 ton/ $\mathrm{km}^{2} /$ ablation were observed in 2015 , while 0.18 ton $/ \mathrm{km}^{2} /$ day and 22.30 ton $/ \mathrm{km}^{2} /$ ablation were observed in 2016 . Furthermore, the anion denudation rate as $1.74 \mathrm{ton} / \mathrm{km}^{2} /$ day and $205.43 \mathrm{ton} / \mathrm{km}^{2} /$ ablation were measured in 2015 , whereas, it was found as $1.40 \mathrm{ton} / \mathrm{km}^{2} /$ day and 170.24 ton/ $\mathrm{km}^{2} /$ ablation in 2016. The ionic flux as well as the denudation rate of the ions is higher in 2015 as compared to 2016, probably due to variation in discharge. Thus, our results suggest that the ionic flux and denudation rate of the ions are largely dependent on the glacier meltwater discharge. 


\section{Hydrogeochemical facies of meltwater and effective $\mathrm{CO}_{2}$ pressure}

The Piper plot is important to establish a relationship between rock type and composition of water by using concentration values of major ions $\left(\mathrm{Ca}^{2+}, \mathrm{Mg}^{2+}, \mathrm{K}^{+}, \mathrm{Na}^{+}\right.$, $\mathrm{HCO}_{3}{ }^{-}, \mathrm{SO}_{4}{ }^{2-}$ and $\mathrm{Cl}^{-}$) (Singh et al. 2014a). We have plotted a trilinear diagram to identify the hydrogeochemical facies of meltwater draining from the Chaturangi in 2015 and 2016. The plot contains one quadrilateral (rhombus) shaped illustration at the top and two triangular shaped diagrams on its left and right at the bottom (Fig. 9).The results obtained from the Piper plot show that the $\mathrm{Ca}-\mathrm{HCO}_{3}$ and $\mathrm{Mg}-\mathrm{HCO}_{3}$ dominated hydrogeochemical facies were present in the study area in year 2015 and 2016, respectively. Variability in the hydrogeochemical facies in 2015 and 2016 might be due to time of interaction among flowing water and minerals, because of gradual changes in meltwater discharge during the study period. The piper plot (Fig. 9) indicates that weak acid $\left(\mathrm{HCO}_{3}\right)$ exceeds over strong acid $\left(\mathrm{SO}_{4}+\mathrm{Cl}\right)$ and alkaline earth metals $(\mathrm{Ca}+\mathrm{Mg})$ exceed over alkalis $(\mathrm{Na}+\mathrm{K})$ for both the years. Such a combination confirms that carbonate weathering followed by silicate are major sources of solutes in the meltwater. The Gibbs plot helps to assess hydrogeochemical facies and water quality controlling mechanism in the catchment area (Kumar et al. 2015). It is also used to establish a relationship between composition of water and lithological characteristics. The Gibbs plots $\left[\mathrm{Cl} /\left(\mathrm{Cl}+\mathrm{HCO}_{3}\right)\right.$ vs TDS and $\mathrm{Na} /(\mathrm{Na}+\mathrm{Ca})$ vs TDS] shows that most samples fall in the rock-water interaction dominance zone and also tend toward the precipitation dominance zone (Fig. 10). This clearly indicates that weathering of rocks mainly control the solute concentration of Chaturangi glacier meltwater with little contribution from the precipitation.

The partial pressure of carbon dioxide or effective $\mathrm{CO}_{2}$ pressure $\left(\mathrm{pCO}_{2}\right)$ of glacier meltwater can be used to describe various hydrological weathering environments (Sharp et al. 1995). The $\mathrm{pCO}_{2}$ of water represents the diffusion rate of $\mathrm{CO}_{2}$ relative to rate of other weathering reactions (Thomas and Raiswell 1984). The low $\mathrm{pCO}_{2}$ values in the solution

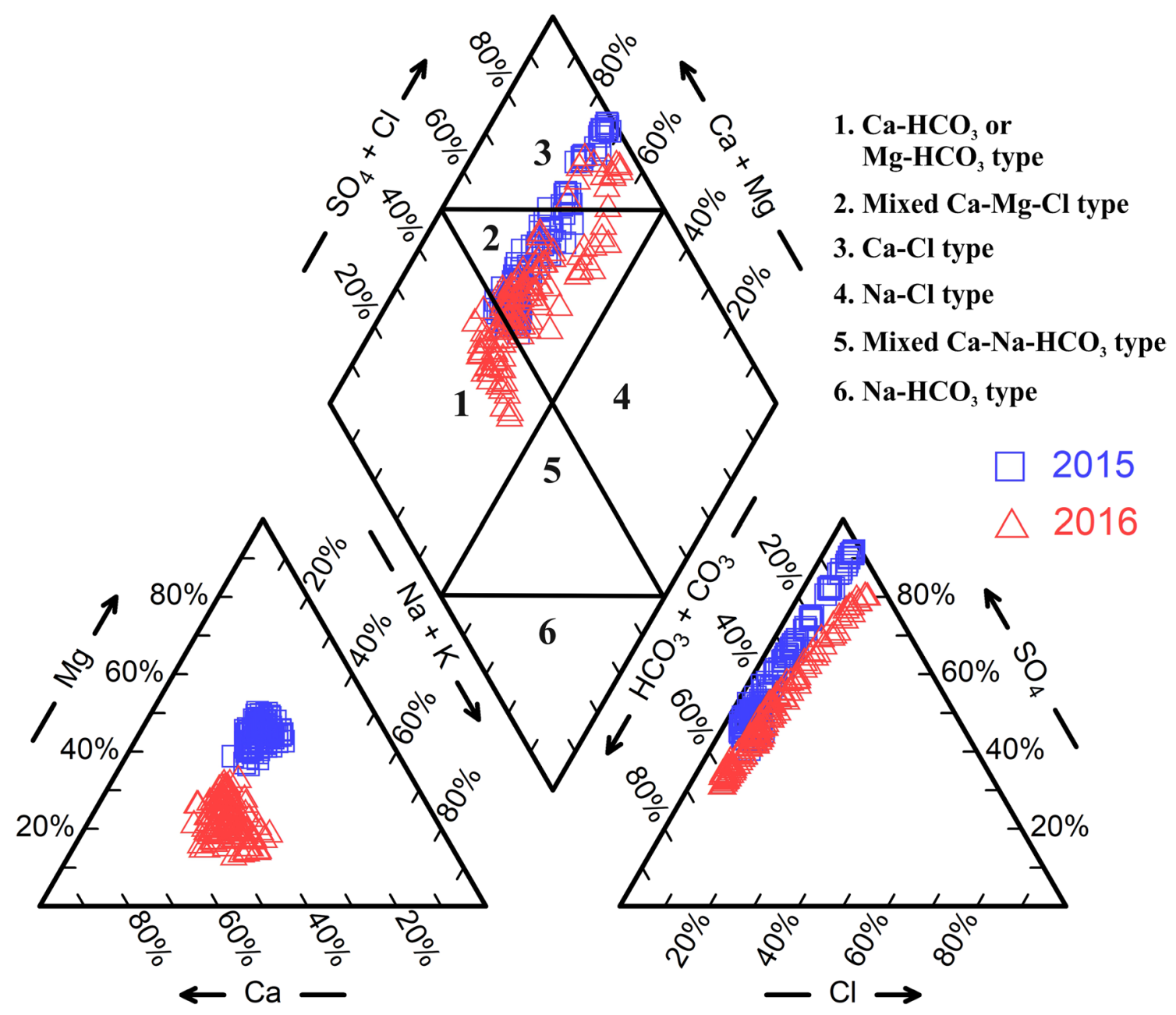

Fig. 9 Piper diagram for ionic concentration to determine chemical characterization and hydrogeochemical facies of meltwater 
Fig. 10 Gibbs plots between $\mathrm{Na} /(\mathrm{Na}+\mathrm{Ca})$ versus TDS and $\mathrm{Cl} /\left(\mathrm{Cl}+\mathrm{HCO}_{3}\right)$ vs TDS shows that rock weathering mainly control the solute concentration in the meltwater followed by precipitation

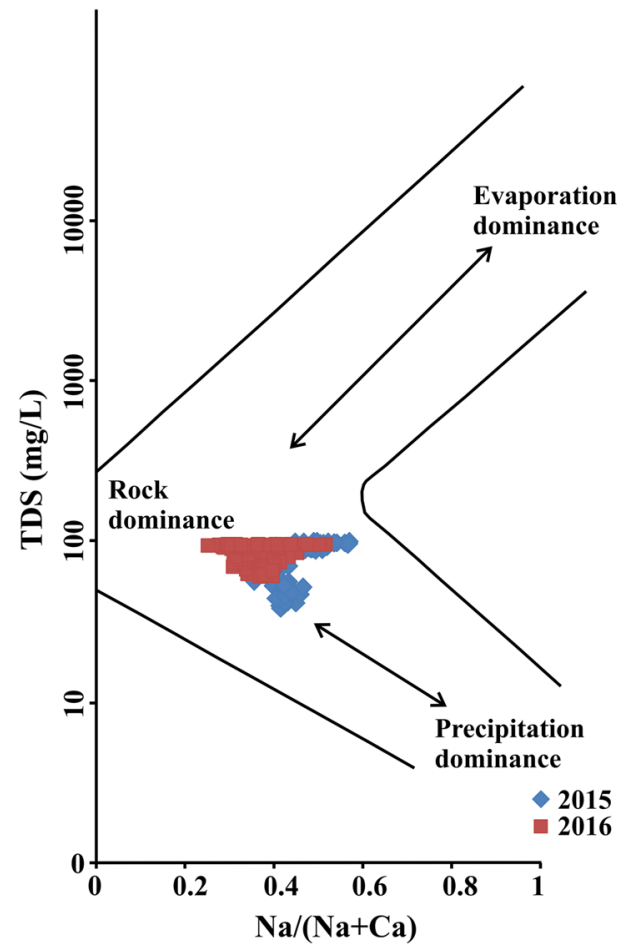

seem appeared when the requirement of protons $\left(\mathrm{H}^{+}\right)$for chemical weathering is higher than diffusion rate of $\mathrm{CO}_{2}$, whereas the high $\mathrm{pCO}_{2}$ values were appeared when the supply of proton is higher than they consumed in the solution (Wadham et al. 1998). The $\mathrm{pCO}_{2}$ was calculated with the help of $\mathrm{HCO}_{3}$ and $\mathrm{pH}$ values of the water (Stumm and Morgan 1981). The average values of $\mathrm{pCO}_{2}$ for Chaturangi glacier meltwater were $10^{-1.2}$ in 2015 and $10^{-1.39}$ in 2016 which is higher than the $\mathrm{pCO}_{2}$ values of atmosphere $\left(10^{-3.5}\right)$. The higher $\mathrm{pCO}_{2}$ values of meltwater than atmosphere in both the years is probably due to high turbulence, low temperature, open system weathering and processes of carbonate weathering (Ahmad and Hasnain 2001; Singh et al. 2012). Our results show that the open system of weathering and higher solubility of $\mathrm{CO}_{2}$ in the meltwater and also suggest that the meltwater is in state of disequilibrium with respect to the surrounding atmosphere.

\section{Water quality analysis of meltwater}

Water quality index (WQI) gives a single number that expresses the overall quality of water at a particular location and time based on several physical and chemical parameters. The main objective of the WQI is to turn hydrochemical data into comprehensible information. Several indices have been developed to summarize the water quality data into easily expressible format. The WQI was first developed by Horton (1965), in which a single value for water quality was generated by calculating multiple test results (Miller et al. 1986).
Following this, several researchers have developed WQI based on the rating of various physicochemical parameters (Miller et al. 1986). In the present study, we have made an attempt to understand the water quality of meltwater draining from the Chaturangi glacier. We have therefore calculated the WQI by using various physicochemical parameters such as EC, pH, TDS, Calcium, Magnesium, Sodium, Sulphate, Chloride and Fluoride (Tables 1 and 2) and the standard permissible values $(S n)$ were followed as per the BIS. The average estimated values $(V n)$ of the physicochemical parameters for ablation periods of 2015 and 2016 were used to calculate the WQI (Tables 1 and 2). Our study proves that the fluoride is mainly responsible for water contamination, followed by $\mathrm{pH}$ and sulphate. Chandaluri et al (2010) also suggested that $\mathrm{pH}$ is a significant parameter responsible for suitability of water for various purposes. Our results show that the WQI values are 46.11 and 35.14 for the years 2015 and 2016, respectively (Table 7), indicating that the values in 2015 are higher than in 2016. However, according to the WQI ranges given by Brown et al (1972) both the index values (46.11 and 35.14) lie within the range of good water quality status (Table 3). Following Brown et al (1972), we believe that the water quality of the Chaturangi glacier meltwater is suitable for drinking in both the years.

\section{Statistical analysis}

Statistical analysis, e.g., correlation matrix is a bivariate method mainly used to determine the correlation 
Table 7 Water quality index values for the ablation periods of year 2015 and 2016

\begin{tabular}{ll}
\hline Year & Index value \\
\hline 2015 & 46.11 \\
2016 & 35.14 \\
\hline
\end{tabular}

among two hydrogeochemical parameters for examining the dependability of different variables among each other (Thilagavathi et al. 2012; Bisht et al. 2018). Therefore, the correlation matrix can be helpful in evaluating the water quality in various environments. A correlation matrix between different hydrogeochemical parameters for year 2015 (a) and 2016 (b) is presented in Table 8. The correlation matrix shows that EC and TDS are positively correlated with each other during both the years (Table 8). It demonstrates that $\mathrm{EC}$ is directly proportional to dissolved ion in the meltwater. A positive correlation between $\mathrm{Ca}^{2+}$ and $\mathrm{Mg}^{2+}\left(r^{2}=0.93\right.$ in 2015 and $r^{2}=0.85$ in 2016), $\mathrm{Ca}^{2+}$ and $\mathrm{HCO}_{3}{ }^{-}\left(r^{2}=0.85\right.$ in 2015 and $r^{2}=0.94$ in 2016) and $\mathrm{Mg}^{2+}$ and $\mathrm{HCO}_{3}{ }^{-}\left(r^{2}=0.89\right.$ in 2015 and $r^{2}=0.84$ in 2016), indicates same sources, i.e., weathering of carbonate rocks. The $\mathrm{Na}^{+}$showed moderate correlation $\left(r^{2}=0.63\right)$ with $\mathrm{K}^{+}$ in 2015 as well as slightly higher correlation $\left(r^{2}=0.71\right)$ in 2016, indicating similar source of both the ions, i.e., partial weathering of silicate rocks.
Further, the factor analyses for different variables, measured from the meltwater of Chaturangi glacier are presented in Table 9. The Factor analysis is also called the principal component analysis which is also helpful for visualization and management of complex dataset (Valder et al. 2012). In present study we used the varimax rotation method for factor analysis. To extract the significant contributing factors, we have employed only those factors with the eigen value greater than one. The two major contributing factors were obtained from the factor analysis in both the years which showed $85.08 \%$ and $84.16 \%$ of the total cumulative variance in year 2015 and 2016, respectively. During the ablation season in 2015, the factor 1 shows strong positive loading of $\mathrm{HCO}_{3}{ }^{-}, \mathrm{F}^{-}, \mathrm{SO}_{4}{ }^{2-}, \mathrm{Na}^{+}, \mathrm{Ca}^{2+}$ and $\mathrm{Mg}^{2+}$ with $49.30 \%$ variance in dataset (Table 9). It indicates dissolved ions contribution from carbonate weathering and dissolution of sulphate minerals. The factor 2 shows high loading of EC, $\mathrm{pH}, \mathrm{Cl}^{-}$and $\mathrm{K}^{+}$with $35.79 \%$ of the variance (Table 9). This reflects contribution of these parameters mainly from the weathering of silicate minerals and atmospheric input. Further, for the ablation period of 2016, the factor 1 indicates positive loading of $\mathrm{EC}, \mathrm{pH}, \mathrm{HCO}_{3}{ }^{-}, \mathrm{SO}_{4}{ }^{2-}, \mathrm{Ca}^{2+}$ and $\mathrm{Mg}^{2+}$ with $45.58 \%$ of the variance (Table 9 ). This indicates the contribution of these parameters largely from the carbonate weathering and sulphate dissolution. The factor 2 represents high positive loading of $\mathrm{F}^{-}, \mathrm{Cl}^{-}, \mathrm{Na}^{2+}, \mathrm{Ca}^{2+}$ and $\mathrm{K}^{+}$with
Table 8 Correlation matrix between different measured physicochemical parameters of Chaturangi glacier meltwater during the ablation period $\mathbf{a}$ 2015 and b 2016

\begin{tabular}{|c|c|c|c|c|c|c|c|c|c|c|c|}
\hline & $\mathrm{EC}$ & $\mathrm{pH}$ & TDS & $\mathrm{Ca}$ & $\mathrm{Mg}$ & $\mathrm{Na}$ & $\mathrm{K}$ & $\mathrm{F}$ & $\mathrm{Cl}$ & $\mathrm{SO}_{4}$ & $\mathrm{HCO}_{3}$ \\
\hline \multicolumn{12}{|l|}{ (a) } \\
\hline EC & 1 & & & & & & & & & & \\
\hline $\mathrm{pH}$ & 0.82 & 1 & & & & & & & & & \\
\hline TDS & 0.96 & 0.82 & 1 & & & & & & & & \\
\hline $\mathrm{Ca}$ & 0.82 & 0.71 & 0.83 & 1 & & & & & & & \\
\hline $\mathrm{Mg}$ & 0.68 & 0.63 & 0.68 & 0.93 & 1 & & & & & & \\
\hline $\mathrm{Na}$ & 0.65 & 0.60 & 0.65 & 0.91 & 0.94 & 1 & & & & & \\
\hline K & 0.70 & 0.73 & 0.70 & 0.70 & 0.71 & 0.63 & 1 & & & & \\
\hline $\mathrm{F}$ & 0.61 & 0.52 & 0.61 & 0.88 & 0.89 & 0.84 & 0.64 & 1 & & & \\
\hline $\mathrm{Cl}$ & 0.52 & 0.54 & 0.52 & 0.53 & 0.61 & 0.65 & 0.56 & 0.44 & 1 & & \\
\hline $\mathrm{SO}_{4}$ & 0.69 & 0.64 & 0.69 & 0.88 & 0.93 & 0.91 & 0.70 & 0.90 & 0.60 & 1 & \\
\hline $\begin{array}{l}\mathrm{HCO}_{3} \\
\text { (b) }\end{array}$ & 0.57 & 0.52 & 0.58 & 0.85 & 0.89 & 0.83 & 0.62 & 0.93 & 0.35 & 0.89 & 1 \\
\hline $\mathrm{EC}$ & 1 & & & & & & & & & & \\
\hline $\mathrm{pH}$ & 0.94 & 1 & & & & & & & & & \\
\hline TDS & 0.98 & 0.94 & 1 & & & & & & & & \\
\hline $\mathrm{Ca}$ & 0.72 & 0.79 & 0.72 & 1 & & & & & & & \\
\hline $\mathrm{Mg}$ & 0.73 & 0.74 & 0.73 & 0.85 & 1 & & & & & & \\
\hline $\mathrm{Na}$ & 0.53 & 0.61 & 0.53 & 0.89 & 0.74 & 1 & & & & & \\
\hline K & 0.58 & 0.69 & 0.58 & 0.75 & 0.80 & 0.71 & 1 & & & & \\
\hline F & 0.34 & 0.39 & 0.34 & 0.63 & 0.55 & 0.85 & 0.57 & 1 & & & \\
\hline $\mathrm{Cl}$ & 0.59 & 0.61 & 0.59 & 0.82 & 0.77 & 0.78 & 0.70 & 0.57 & 1 & & \\
\hline $\mathrm{SO}_{4}$ & 0.75 & 0.70 & 0.75 & 0.71 & 0.76 & 0.60 & 0.64 & 0.43 & 0.72 & 1 & \\
\hline $\mathrm{HCO}_{3}$ & 0.73 & 0.78 & 0.73 & 0.94 & 0.84 & 0.83 & 0.71 & 0.60 & 0.87 & 0.71 & 1 \\
\hline
\end{tabular}


Table 9 Factor analysis of the Chaturangi glacier metlwater samples collected during the ablation period 2015 and 2016

\begin{tabular}{|c|c|c|c|c|c|c|}
\hline \multirow[t]{2}{*}{ Variables } & \multicolumn{3}{|c|}{$2015(n=118)$} & \multicolumn{3}{|c|}{$2016(n=122)$} \\
\hline & Factor 1 & Factor 2 & Communalities & Factor 1 & Factor 2 & Communalities \\
\hline $\mathrm{EC}$ & - & 0.80 & 0.80 & 0.94 & - & 0.90 \\
\hline $\mathrm{pH}$ & - & 0.86 & 0.83 & 0.90 & - & 0.89 \\
\hline $\mathrm{HCO}_{3}$ & 0.94 & - & 0.94 & 0.69 & 0.64 & 0.88 \\
\hline $\mathrm{F}$ & 0.92 & - & 0.93 & - & 0.91 & 0.84 \\
\hline $\mathrm{Cl}$ & - & 0.73 & 0.59 & 0.57 & 0.67 & 0.78 \\
\hline $\mathrm{SO}_{4}$ & 0.84 & 0.47 & 0.93 & 0.78 & - & 0.74 \\
\hline $\mathrm{Na}$ & 0.82 & 0.47 & 0.89 & - & 0.89 & 0.94 \\
\hline $\mathrm{Ca}$ & 0.79 & 0.54 & 0.92 & 0.67 & 0.68 & 0.91 \\
\hline $\mathrm{Mg}$ & 0.85 & 0.48 & 0.95 & 0.72 & 0.56 & 0.84 \\
\hline K & 0.43 & 0.74 & 0.74 & 0.58 & 0.60 & 0.70 \\
\hline Eigen value & 4.93 & 3.58 & & 4.56 & 3.86 & \\
\hline$\%$ of variance & 49.30 & 35.79 & & 45.58 & 38.57 & \\
\hline$\%$ of cumulative variance & 49.30 & 85.08 & & 45.58 & 84.16 & \\
\hline
\end{tabular}

$38.57 \%$ of the variance in data (Table 9), demonstrating the contribution of these ions mainly from the silicate weathering and atmospheric deposition.

\section{Conclusion}

The analysis of Chaturangi glacier meltwater samples collected during the ablation seasons of 2015 and 2016 were carried out to understand the hydrogeochemical processes, regulating the solute dynamics of meltwater. Our study also gives insight on the chemical weathering process and mineralogy of surrounding rocks to identify the sources of ions and their controlling factors. The hydrogeochemical study of meltwater samples indicates that meltwater is slightly acidic with $\mathrm{Ca}-\mathrm{HCO}_{3}$ and $\mathrm{Mg}-\mathrm{HCO}_{3}$ dominated hydrochemical facies in years 2015 and 2016, respectively. The concentration of cations in the meltwater sample shows that $\mathrm{Ca}^{2+}$ is foremost cation followed by $\mathrm{Mg}^{2+}, \mathrm{Na}^{+}$and $\mathrm{K}^{+}$in 2015 , while $\mathrm{Ca}^{2+}$ is leading cation followed by $\mathrm{Na}^{+}, \mathrm{K}^{+}$and $\mathrm{Mg}^{2+}$ in 2016. Among the anions, $\mathrm{HCO}_{3}{ }^{-}$is foremost followed by $\mathrm{SO}_{4}{ }^{2-}, \mathrm{Cl}^{-}$and $\mathrm{F}^{-}$in both the years. The low $\mathrm{Na}+\mathrm{K} / \mathrm{TZ}^{+}$ ratio and high $(\mathrm{Ca}+\mathrm{Mg}) /(\mathrm{Na}+\mathrm{K})$ and $\mathrm{Ca}+\mathrm{Mg} / \mathrm{TZ}^{+}$ratios for both the years suggest that the weathering of carbonate is primary mechanism, controlling the hydrogeochemistry of Chaturangi meltwater with diminutive contribution by silicate weathering. The $\mathrm{C}$ and $\mathrm{S}$ ratios reveal that the weathering is primarily controlled by the carbonation reactions. In addition, the average equivalent ratios of $\mathrm{Na} / \mathrm{Cl}$ and $\mathrm{K} / \mathrm{Cl}$ of meltwater are considerably higher than the marine aerosols, indicating a lesser contribution of atmospheric input in glacier meltwater. The Gibbs plot also suggests that ionic concentration of meltwater is mainly controlled by weathering of rocks and little contribution from atmosphere. The correlation matrix and factor analysis also indicate that the hydrogeochemical characteristics of the meltwater are chiefly controlled by the weathering processes with a minor atmospheric input. The results derived from the petrographic analysis suggest that the rocks in the catchment area are rich in alkali feldspar, plagioclase feldspar, biotite, quartz with a little amount of tourmaline, garnet, staurolite, pyrite and chalcopyrite, which contribute the major anions and cations. The higher $\mathrm{pCO}_{2}$ values of the meltwater than the atmosphere point to an open system of weathering and higher solubility of $\mathrm{CO}_{2}$ in the meltwater. Further we believe that the meltwater is in the state of disequilibrium with respect to the surrounding atmosphere. The solute fluxes show that denudation rate of the anions from the glacier catchment were 205.43 and 170.24 ton $/ \mathrm{km}^{2} /$ ablation in 2015 and 2016 , respectively, whereas the cation denudation rate were 32.84 and 22.30 ton $/ \mathrm{km}^{2} /$ ablation during 2015 and 2016, respectively. The WQI results show that the status of water quality of glacier meltwater was of good quality for both the ablation seasons. Since the glacier meltwater is being used for drinking, irrigation and industrial purposes, it seems crucial to monitor its quality on a regular basis to ensure its suitability for various purposes.

Acknowledgements The authors are grateful to the Director, G.B. Pant National Institute, Kosi-Katarmal, Almora for providing us necessary working facilities in the field and laboratory. We are also thankful to Vikram Negi and Nikesh Pandey for their assistance in the field.

Author contribution All authors contributed to the conception and design of this study. HB and BSK drafted the whole manuscript. Data collection, material preparation and analysis were performed by HB, KK, AKT, PCA, SKS, VA and MT. AKT and RU provided comments to improve the manuscript.

Funding The research was financed by the SERB, (Grant No. SR/ DGH/58/2013), DST, New Delhi, Govt. of India. 


\section{Declarations}

Conflicts of interest The authors declare no conflict of interest.

Ethical approval This manuscript does not contain any studies involving animals and human participants performed by any of the authors.

Open Access This article is licensed under a Creative Commons Attribution 4.0 International License, which permits use, sharing, adaptation, distribution and reproduction in any medium or format, as long as you give appropriate credit to the original author(s) and the source, provide a link to the Creative Commons licence, and indicate if changes were made. The images or other third party material in this article are included in the article's Creative Commons licence, unless indicated otherwise in a credit line to the material. If material is not included in the article's Creative Commons licence and your intended use is not permitted by statutory regulation or exceeds the permitted use, you will need to obtain permission directly from the copyright holder. To view a copy of this licence, visit http://creativecommons.org/licenses/by/4.0/.

\section{References}

Adimalla N, Dhakate R, Kasarla A, Taloor AK (2020) Appraisal of groundwater quality for drinking and irrigation purposes in Central Telangana India. Groundw Sustain Dev 10:100334. https:// doi.org/10.1016/j.gsd.2020.100334

Adimalla N, Taloor AK (2020) Hydrogeochemical investigation of groundwater quality in the hard rock terrain of South India using Geographic Information System (GIS) and groundwater quality index (GWQI) techniques. Groundw Sustain Dev 10:100288. https://doi.org/10.1016/j.gsd.2019.100288

Ahmad S, Hasnain SI (2001) Chemical characteristics of stream draining from Dudu glacier: an Alpine meltwater stream in Ganga Headwater, Garhwal Himalaya. J China Univ Geosci 12(1):75-83

APHA (American Public Health Association) (2005) Standard methods for examination of water and wastewater, 21 st edn. American Public Health Association, Washington, DC.

Azetsu-Scott K, Petrie B, Yeats P, Lee C (2012) Composition and fluxes of freshwater through Davis Strait using multiple chemical tracers. J Geophys Res 117(C12):1-12. https://doi.org/10.1029/ 2012JC008172

Bali R, Awasthi DD, Tiwari NK (2003) Neotectonic control on the geomorphic evolution of the Gangotri Glacier Valley Garhwal Himalaya. Gond Res 6(4):829-838. https://doi.org/10.1016/ S1342-937X(05)710285

Bhatt BK (1963) Preliminary study of the Bhagirathi basin between Uttarkashi and Gomukh. In Proceeding national symposium. On Himalayan geology, Calcutta. Geological Society of India miscelaneous publicaion, 15:1-8.

Bisht H, Arya PC, Kumar K (2018) Hydro-chemical analysis and ionic flux of meltwater runoff from Khangri Glacier, West Kameng, Arunachal Himalaya, India. Environ Earth Sci 77:1-16. https:// doi.org/10.1007/s12665-018-7779-6

Bisht H, Kotlia BS, Kumar K et al (2020a) Estimation of suspended sediment concentration and meltwater discharge draining from the Chaturangi glacier Garhwal Himalaya. Arab J Geosci 13(6):1-12. https://doi.org/10.1007/s12517-020-5204-w4

Bisht H, Kotlia BS, Kumar K et al (2021) Sources of solute and hydrochemical analysis of Gangotri Glacier Meltwater. In: Taloor AK et al (eds) Water, cryosphere, and climate change in the
Himalayas. Springer Nature, Switzerland, pp 259-278. https:// doi.org/10.1007/978-3-030-67932-3 16

Bisht H, Kotlia BS, Kumar K, Joshi LM, Sah SK, Kukreti M (2020b) Estimation of the recession rate of Gangotri glacier, Garhwal Himlaya (India) through kinematic GPS survey and satellite data. Environ Earth Sci 13(6):1-12. https://doi.org/10.1007/ s12665-020-09078-0

Bisht H, Rani M, Kumar K, Sah S, Arya PC (2019) Retreating rate of Chaturangi glacier, Garhwal Himalaya, India derived from kinematic GPS survey and satellite data. Curr Sci 116:304-311. https://doi.org/10.18520/cs/v116/i2/304-311

Bisht H, Sah S, Kumar K, Arya PC, Tewari M (2017) Quantification of variability in discharge and suspended sediment concentration of meltwater of Gangotri glacier, Garhwal Himalaya. ENVIS Bull Himal Ecol 25:10-16

BIS (1991) Indian standards drinking water specification, Bureau of Indian Standards, IS 10500

Brown GH, Tranter M, Sharp M (1996) Subglacial chemical erosionseasonal variations in solute provenance, Haut glacier d'Arolla, Switzerland. Anna Glaciol 22:25-31. https://doi.org/10.3189/ 1996AoG22-1-25-31

Brown RM, Mccleiland NJ, Deiniger RA, Connor MFO (1972) Water quality index- crashing the psychological barrier. In: Thomas WA (ed) Indicators of environmental quality. Springer, pp 173-182. https://doi.org/10.1007/978-1-4684-2856-8_15

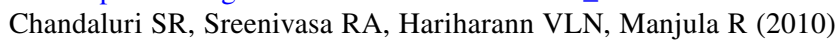
Determination of water quality index of some areas in Guntur district Andhra Pradesh. IJABPT 1:79-86

Clow DW, Mast MA (2010) Mechanisms for chemostatic behavior in catchments: implications for $\mathrm{CO} 2$ consumption by mineral weathering. Chem Geo 269:40-51. https://doi.org/10.1016/j.chemgeo. 2009.09.014

Collins DN (1979) Hydrochemistry of meltwater draining from an Alpine glacier. Arctic Antarc Alp Res 11:307-324. https://doi. org/10.3189/S0022143000029877

Dickinson WR (1970) Interpreting detrital modes of greywake and arkose. J Sediment Petrol 40:695-707

Dimri AP, Yasunari T, Kotlia BS, Mohanty UC, Sikka DR (2016) Indian winter Monsoon; present and past. Earth Sci Rev 163:297322. https://doi.org/10.1016/j.earscirev.2016.10.008

Dyurgerov MB, Meier MF (1997) Twentieth century climate change: evidence from small glaciers. Proc National Acad Sci United States Am 97:1406-1411

Fang F, Zhongqin L, Shuang J, Jhiwen D, Feiteng W (2012) Hydrochemical characteristics and solute dynamics of meltwater runoff of Urumqi Glacier No.1, Eastern Tianshan Northwest China. J Mount Sci 9:472-482. https://doi.org/10.1007/s11629-012-2316-7

Gaillardet J, Dupre B, Louvat P, Allegre CJ (1999) Global silicate weathering and silicate weathering and $\mathrm{CO}_{2}$ consumption rates deduced from the chemistry of large rivers. Chem Geo 159:3-30. https://doi.org/10.1016/S0009-2541(99)00031-5

Gazzi P (1966) Le arenariedel flysch sopracretaceodell' appennino modenese: correlazioniconil flysch di monghidoro. Mineralogica e Petrographica Acta 12:69-97

Gholizadeh MH, Melesse AM, Reddi L (2016) Spaceborne and airborne sensors in water quality assessment. Int J Remote Sens 37(14):3143-3180. https://doi.org/10.1080/01431161.2016.11904 77

Horton RK (1965) An index number system for rating water quality. J Water Pollut Control Fed 37(3):300-306

Hallet B (1976) Deposits formed by subglacial precipitation of $\mathrm{CaCO}_{3}$. Geol Soc Ame Bull 87:1003-1015

Hasnain SI, Thayyen RJ (1999) Discharge and suspended-sediment concentration of meltwaters, draining from the Dokriani glacier, Garhwal Himalaya, India. J Hydrol 218:191-198. https://doi.org/ 10.1016/10.1016/s00221694(99)00033-5 
Huang X, Sillanpää M, Duo B, Gjessing ET (2008) Water quality in the Tibetan Plateau: metal contents of four selected rivers. Environ Pollut 156(2):270-277

Hubbard B, Glassar N (2005) Field techniques in glaciology and glacial geomorphology. Wiley, England

Khadka UR, Ramanathan AL (2012) Major ion composition and seasonal variation in the Lesser Himalayan lake: case of Begnas Lake of Pokhara Valley Nepal. Arab J Geosci 7(4):1-10. https://doi.org/ $10.1007 / \mathrm{s} 12517-012-0677-4$

Krishnaswami S, Singh SK (2005) Chemical weathering in the river basins of the Himalaya. India Curr Sci 89(5):841-849

Kristiansen SM, Yde JC, Barcena TG, Jakobsen BH, Olsen J, Knudsen NT (2013) Geochemistry of groundwater in front of a warm-based glacier in Southeast Greenland. Geogr Ann: Ser A Phys Geogr 95(2):97-108. https://doi.org/10.1111/geoa.12003

Kulkarni AV, Karyakarte Y (2014) Observed changes in Himalayan glaciers. Curr Sci 106(2):237-244

Kumar K, Miral MS, Joshi S, Pant N, Joshi V, Joshi LM (2009) Solute dynamics of meltwater of Gangotri glacier, Garhwal Himalaya. India Environ Geol 58(6):1151-1159. https://doi.org/10. 1007/s00254-008-1592-6

Kumar R, Kumar R, Singh A et al (2019) Hydrogeochemical analysis of meltwater draining from Bilare Banga glacier. Western Himalaya Acta Geophys 67(2):651-660. https://doi.org/10. 1007/s11600-019-00262-w

Kumar R, Singh S, Singh A et al (2018) Dynamics of suspended sediment load with respect to summer discharge and temperatures in Shaune Garang glacierized catchment, Western Himalaya. Acta Geophys 66:1109-1120. https://doi.org/10.1007/ s11600-018-0184-4

Kumar SK, Logeshkumaran A, Magesh NS, Godson PS, Chandrasekar N (2015) Hydro-geochemistry and application of water quality index (WQI) for groundwater quality assessment, Anna Nagar, part of Chennai city, Tamil Nadu, India. App Water Sci 5:335-343. https://doi.org/10.1007/s13201-014-0196-4

Lambers H, Raven JA, Shaver GR, Smith SE (2008) Plant nutrientacquisition strategies change with soil age. Trends Ecol Evol 23:95-103. https://doi.org/10.1016/j.tree.2007.10.008

Lintern A, Webb JA, Ryu D et al (2018) Key factors influencing differences in stream water quality across space. Wires Water 5:e1260. https://doi.org/10.1002/wat2.1260

Meybeck M (1984) Atmospheric inputs and river transport of dissolve substances. In: Webb BW (ed) Dissolved loads of rivers and surface water quantity/quality relationships. IAHS publication, Wallingford, pp 173-192

Miller WW, Joung HM, Mahannah CN, Garrett JR (1986) Identification of water quality differences in Nevada through index application. J Environ Qual 15(3):265-272. https://doi.org/10. 2134/jeq1986.00472425001500030012x

Narany TS, Ramli MF, Aris AZ, Sulaiman WNA, Juahir H, Fakharian K (2014) Identification of the hydrogeochemical processes in groundwater using classic integrated geochemical methods and geostatistical techniques in Amol-Babol plain Iran. Scientific World J. https://doi.org/10.1155/2014/419058

Negrel P, Allegre CJ, Dupre B, Lewin E (1993) Erosion sources determined by inversion of major and trace element ratios in river water: the Congo basin case. Earth Planet Sci Lett 120:5976. https://doi.org/10.1016/0012-821X(93)90023-3

Noh H, Huh Y, Qin J, Ellis A (2009) Chemical weathering in the three rivers region of Eastern Tibet. Geochim Cosmochim Acta 73:1857-1877. https://doi.org/10.1016/j.gca.2009.01.005

Orr EN, Owen LA, Saha S, Caffee MW (2019) Rates of rockwall slope erosion in the upper Bhagirathi catchment, Garhwal Himalaya. Earth Surf Process Land 44:3108-3127. https://doi. org/10.1002/eps.4720
Ostrem G (1975) Sediment transport in glacial meltwater stream. In: Jopling AV, McDonald BC (eds) Glacio-fluvial and Glaciolacustrine sedimentation. Society of Economic palaeontologists and Mineralogists, pp 101-122

Qian JZ, Li RZ, RZ, et al (2004) Health risk assessment on source water quality of urban water supply. J Hydrau Eng 1:1-5

Raina VK, Srivastava D (2008) Glacier atlas of India. Miscellaneous publication, Geological Society of India, Bangalore, p 315

Ramadas M, Samantaray AK (2018) Applications of remote sensing and GIS in water quality monitoring and remediation: a stateof-the-art review. In: Bhattacharya $\mathrm{S}$ et al (eds) Water remediation, energy, environment, and sustainability. Springer Nature, Singapore. https://doi.org/10.1007/978-981-10-7551-3

Raymo ME, Ruddiman WF (1992) Tectonic forcing of late Cenozoic climate. Nature 359:117-122. https://doi.org/10.1038/359117a0

Sadat N (2012) Study of fluoride concentration in the river (Godavari) and groundwater of Nanded city. Int J Eng Invent 1:11-15

Sah S, Bisht H, Kumar K, Tiwari A, Tewari M, Joshi H (2017) Assessment of hydrochemical properties and annual variation in meltwater of Gangotri glacier system. ENVIS Bull Himalayan Ecol 25:17-23

Searle MP, Noble SR, Hurford AJ, Rex DC (1999) Age of crustal melting, emplacement and exhumation history of the Shivling leucogranite Garhwal Himalaya. Geol Magazine 136(5):513-525. https://doi.org/10.1017/s0016756899002885

Sharma S, Chand P, Bisht P et al (2016) Factors responsible for driving the glaciation in the Sarchu Plain, eastern Zanskar Himalaya, during the late Quaternary. J Quat Sci 31(5):495-511. https://doi. org/10.1002/jqs. 2874

Sharma P, Ramanathan AL, Pottakkal J (2013) Study of solute sources and evolution of hydrogeochemical processes of the Chota Shigri Glacier meltwaters, Himanchal Himalaya India. Hydrol Sci J 58(5):1128-1143. https://doi.org/10.1080/02626667.2013.802092

Sharp M, Tranter M, Brown GH, Skidmore M (1995) Rates of chemical denudation and $\mathrm{CO}_{2}$ drawdown in a glacier-covered alpine catchment. Geology 23(1):61-64. https://doi.org/10.1130/00917 613(1995)023\%3c0061:ROCDAC\%3e2.3.CO;2

Shin W, Ryu J, Park Y, Lee K (2011) Chemical weathering and associated $\mathrm{CO}_{2}$ consumption in six major river basins, South Korea. Geomorphology 129:334-341. https://doi.org/10.1016/j.geomo rph.2011.02.028

Singh AK, Hasnain SI (1998) Major ion chemistry and weathering control in a high altitude basin: Alaknanda River, Garhwal Himalaya, India. Hydrol Sci J 436:825-884. https://doi.org/10.1080/02626 669809492181

Singh VB, Keshari AK, Ramanathan AL (2019) Major ion chemistry and atmospheric $\mathrm{CO}_{2}$ consumption deduced from the Batal glacier, Lahaul-Spiti valley, Western Himalaya, India. Environ Develop Sustain 19:1-19. https://doi.org/10.1007/s10668-019-00501-6

Singh VB, Ramanathan AL (2017) Hydrogeochemistry of the Chhota Shigri glacier meltwater, Chandra basin, Himachal Pradesh, India: solute acquisition processes, dissolved load and chemical weathering rates. Environ Earth Sci 76(5):223-232. https://doi.org/10. 1007/s12665-017-6465-4

Singh VB, Ramanathan AL, Pottakkal JG, Kumar M (2014a) Seasonal variation of the solute and suspended sediment load in Gangotri Glacier meltwater, central Himalaya, India. J Asian Earth Sci 79:224-234. https://doi.org/10.1016/j.jseaes.2013.09.010

Singh VB, Ramanathan AL, Pottakkal JG, Kumar M (2014) Hydrogeochemisty of meltwater of the Chaturangi glacier, Garhwal Himalaya, India. Proc Nat Acad Sci India 85(1):187-195. https://doi. org/10.1007/s40010-014-0181-1

Singh VB, Ramanathan AL, Pottakkal JG et al (2012) Chemical characterisation of meltwater draining from Gangotri Glacier, Garhwal Himalaya India. J Earth Syst Sci 121(3):625-636. https://doi.org/ 10.1007/s12040-012-0177-7 
Singh VB, Ramanathan AL, Pottakkal JG et al (2013) Hydrochemistry of meltwater emerging from Raktvarn glacier, Central Himalaya, India. Climate change and Himalayan ecosystem-indicator, bio and water resources, pp 109-118.

Singh VB, Ramanathan AL, Sharma P, Pottakkal JG (2015) Dissolved ion chemistry and suspended sediment characteristics of meltwater draining from Chhota Shigri Glacier, western Himalaya, India. Arab J Geosci 8:281-293. https://doi.org/10.1007/ s12517-013-1176-y

Sood V, Gupta S, Gusain HS, Singh S, Taloor AK (2021a) Topographic controls on subpixel change detection in Western Himalayas. Remote Sensing App: Society and Environ. https://doi.org/10. 1016/j.rsase.2021.100465

Sood V, Gusain HS, Gupta S, Taloor AK, Singh S (2021b) Detection of snow/ice cover changes using subpixel-based change detection approach over Chhota-Shigri glacier, Western Himalaya, India. Quat Int 575:204-212. https://doi.org/10.1016/j.quaint.2020.05. 016

Sood V, Singh S, Taloor AK, Prashar S, Kaur R (2020) Monitoring and mapping of snow cover variability using topographically derived NDSI model over north Indian Himalayas during the period 2008-19. Appl Comp Geosci. https://doi.org/10.1016/j. acags. 2020.100040

Souchez RA, Lemmens MM (1987) Solutes. In: Gurnell AM, Clark MJ (eds) Glacio-fluvial sediment transfer. Wiley, United Kingdom, pp 285-303

Stumm W, Morgan JJ (1981) An introduction emphasizing chemical equilibria in natural waters. In: Stumm W, Morgan JJ (eds) Aquatic chemistry, 2nd edn. Wiley, New York, pp 230-258

Taloor AK, Pir RA, Adimalla N, Ali S, Manhas DS, Roy S, Singh AK (2020) Spring water quality and discharge assessment in the Basantar watershed of Jammu Himalaya using geographic information system (GIS) and water quality Index (WQI). Groundw Sustain Dev 10:100364. https://doi.org/10.1016/j.gsd.2020.100364

Thayyen RJ, Gergan JT, Dobhal DP (2007) Role of glaciers and snow cover on headwater river hydrology in monsoon regime-microscale study of Din Gad catchment, Garhwal Himalaya. India Curr Sci 92(3):376-382

Thilagavathi R, Chidambaram S, Prasanna MV, Thivya C, Singaraja $C$ (2012) A study on groundwater geochemistry and water quality in layered aquifers system of Pondicherry region, Southeast India. App Water Sci 2:253-269. https://doi.org/10.1007/ s13201-012-0045-2

Thomas AG, Raiswell R (1984) Solute acquisition in glacial meltwaters, II Glacier d'Argentiere (French Alps): bulk meltwaters with open system characteristics. J Glaciol 30(104):44-48. https://doi. org/10.3189/S0022143000008479

Thomas J, Joseph S, Thrivikramji KP (2015) Hydro-chemical variations of a tropical mountain river system in a rain shadow region of the southern Western Ghats, Kerala, India. App Geochem 63:456-471. https://doi.org/10.1016/j.apgeochem.2015.03.018

Tiwari S, Kumar A, Gupta AK et al (2018) Hydrochemistry of meltwater draining from Dokriani Glacier during early and late ablation season. West Central Himalaya Himal Geo 39(1):121-132

Tranter M, Sharp M, Brown GH et al (1997) Variability in the chemical composition of in-situ subglacial meltwaters. Hydrol Process 11:59-77. https://doi.org/10.1002/(SICI)1099-1085

Usali N, Ismail MH (2010) Use of remote sensing and GIS in monitoring Water Quality. J Sustain Dev 3(3):228-238. https://doi.org/10. 5539/jsd.v3n3p228

Valder JF, Long AJ, Davis AD, Kenner SJ (2012) Multivariate statistical approach to estimate mixing proportions for unknown end members. J Hydrol 460:65-76. https://doi.org/10.1016/j.jhydrol. 2012.06.037

Vohra CP (1988) Gangotri glacier. Indian Mountaineer, Indian Mountaineering Foundation, pp 51-58

Wadham JL, Hodson AJ, Tranter M, Dowdeswell JA (1998) The hydrochemistry of meltwater draining a polythermal-based, high Arctic glacier, South Svalbard. Hydrol Process 12:1825-1849. https:// doi.org/10.1002/(SICI)1099-1085(19981015)12:12\%3c1825:: AID-HYP669\%3e3.0.CO;2-R

Xu H, Hou Z, An Z, Liu X, Dong J (2010) Major ion chemistry of waters in Lake Qinghai catchments, NE Qinghai-Tibet plateau, China. Quat Int 212:35-43. https://doi.org/10.1016/j.quaint.2008. 11.001

Publisher's Note Springer Nature remains neutral with regard to jurisdictional claims in published maps and institutional affiliations.

\section{Authors and Affiliations}

\section{Harish Bisht ${ }^{1}$ [D $\cdot$ Bahadur Singh Kotlia ${ }^{1} \cdot$ Kireet Kumar $^{2} \cdot$ Ajay Kumar Taloor $^{3} \cdot$ Prakash Chandra Arya $^{4}$. Saurabh Kumar Sah ${ }^{2} \cdot$ Vasudha Agnihotri $^{2} \cdot$ Mohit Tewari $^{2} \cdot$ Rajeev Upadhyay ${ }^{1}$}

\author{
Bahadur Singh Kotlia \\ bahadur.kotlia@gmail.com \\ Kireet Kumar \\ kireet@gbpihed.nic.in \\ Ajay Kumar Taloor \\ ajaytaloor@gmail.com \\ Prakash Chandra Arya \\ aryapraky@gmail.com \\ Saurabh Kumar Sah \\ saurabhsah289@gmail.com \\ Vasudha Agnihotri \\ vasudha@gbpihed.nic.in \\ Mohit Tewari \\ tewari.mohit258@gmail.com
}

Rajeev Upadhyay

Rajeev_up@yahoo.com

1 Centre of Advanced Study in Geology, Kumaun University, Nainital, Uttarakhand 263002, India

2 G. B. Pant, National Institute of Himalayan Environment, Kosi-Katarmal, Almora, Uttarakhand 263643, India

3 Department of Remote Sensing and GIS, University of Jammu, Jammu 180006, India

4 Centre of Earth Sciences, Indian Institute of Science, Bengaluru 560012, India 